\title{
Organisational Strategies for Competitive Advantage in the Construction Industry: Chinese Dominance in Southern Africa
}

\author{
"Daniel Soares Fernandes' and George Joseph",2
}

\begin{abstract}
First submission: 5 November 2018; Accepted: 17 November 2019; Published: 15 December 2020
To cite this article: Daniel Soares Fernandes and George Joseph (2020). Organisational strategies for competitive advantage in the construction industry: Chinese dominance in Southern Africa. Journal of Construction in Developing Countries, 25(2): 1-38. https://doi.org/10.21315/jcdc2020.25.2.1.
\end{abstract}

To link to this article: https://doi.org/10.21315/jcdc2020.25.2.1

\begin{abstract}
Chinese enterprises are presently dominating various sectors of businesses abroad, offering a wide range of low to high-end quality products and services. The construction sector in Africa is now being dominated by Chinese multinational contractor companies, who find in Africa their next preferable market to grow. The available literature on the field has serious gaps in explaining which organisational strategies increase the competitive advantage and the market dominance of Chinese multinational contractors, especially in the Southern African region. This research aims to uncover the organisational strategies, implemented by Chinese multinational contractors operating in the Southern African region, who have paved the way and consolidated their success in the region. Through a mixed methods process, qualitative and quantitative data are obtained. The construction markets of the Southern African region are analysed (environmental analysis) and the main multinational Chinese contractors are identified, through a literature review and organisational analysis. Several organisational strategies are shortlisted and, finally, through an online questionnaire, the opinions of the participants to rank the organisational strategies previously identified in terms of contribution to the actual success, copying capability, etc., are carried out. The findings revealed that the capability to offer a lower price for construction services, the easy access to loans and funds from the organisation's home government and the capability to trade debt for local resources, such as wood, land and minerals are the organisational strategies that mostly contributed to the recent Chinese contractor dominance in the Southern African construction market.
\end{abstract}

Keywords: Chinese multinational contractor company, Organisational strategy, Competitive advantage, Construction industry, Environmental analysis, Market dominance

\section{INTRODUCTION}

This management research project is dedicated to uncovering the organisational strategies as implemented by Chinese multinational construction companies (CMCCs) operating in Southern Africa (South African Development Community member countries), which paved the path to their recent success, in South Africa and international construction industry. The research's goal is to increase the practical and theoretical knowledge of the industry of construction by explaining the history of success of CMCCs. The research aims also to examine if such organisational strategies are ethical and sustainable.

\footnotetext{
University of Roehampton Online, Roehampton Ln, London SW 15 5PU, UNITED KINGDOM 2DDU KAUSHAL KENDRA, Cochin University of Science and Technology (CUSAT), Kalamassery, Kochi, Kerala 682022, INDIA

*Corresponding author: danielsoaresfernandes@gmail.com
} 
Presently, the global industry of construction is being dominated by CMCCs. Public and private construction-related tenders opened to international bidders are being easily won by Chinese contractor companies who offer proposals with a vast range of quality, scope, price and financing possibilities to its clients. More than 60 CMCCs are present in Engineering News-Record (ENR) List of Top International Contractors, which, on its own, is a sign of their dominance. Adding to this record, CMCCs detain a market share of the international construction industry of more than $20 \%$, which translates on revenue related to the construction project's backlog of more than USD100 billion in 2016. Besides these facts, available in ENR, several current literature examples depict the Chinese contractor dominance in the international market, especially in Africa (Cheng, 2010; Chen et al., 2007; Corkin, 2011; Flanagan et al., 2013; Lan, 2011; Lu et al., 2013; Mwangi, 2011).

\section{RESEARCH OBJECTIVES}

The study aims to increase the practical and theoretical knowledge on organisational strategies, focusing on the setting of the construction industry, more specifically, exploring the organisational strategies that led to the recent success of Chinese multinational contractor companies in dominating the public and private construction markets of 15 countries of Southern Africa. Its main objectives are:

1. to identify which CMCCs are present in the Southern Africa countries studied,

2. to verify if they are dominating the actual public and private construction markets in the region,

3. to research which organisational strategies are being implemented and practised in the CMCCs identified,

4. to verify if there is any correlation between the region's macro and microenvironments and the success on the market share of the identified CMCCs and

5. to study which organisational strategies identified contribute more and less to the CMCCs success.

\section{RESEARCH SIGNIFICANCE}

This research can serve as a foundation for other construction companies to mimic the strategy adopted by the studied CMCCs or to implement other strategies identified and suggested in the research to regain competitive advantage. It can also inspire CMCCs to find ways and methods to protect their actual position on the Southern African market. 
The following list presents some examples of types of stakeholders that can find benefits in the performed research:

1. CMCC scan identifies fragilities in their actual organisational strategy and can improve, contributing to an increase in their competitive advantages.

2. CMCCs direct and indirect competitors can identify efficient organisational strategies that are feasible to implement in their organisation, leading to an increase in their competitive advantage.

3. Actual and future clients of CMCCs can familiarise themselves better with CMCCs' organisational strategies, their advantages, their disadvantages and their culture.

4. Construction industry enthusiasts and academics can increase their knowledge of the Southern African construction industry and on organisational strategies that can lead to success or failure.

\section{RESEARCH QUESTIONS}

"Which organisational strategies, adopted by CMCCs, contributed most to their achievement in the market of Southern Africa and can competitors implement them with ease?"

This research question can be broken down in scope into more manageable supporting questions:

1. How did a number of Chinese contractor companies grow from unprofitable firms, with a low local market share in their own country, to dominating the industry of construction overseas and in China and, such as in various countries of the Southern Africa region?

2. Which organisational strategies were developed and implemented that led to such growth?

3. Which of the organisational strategies identified before contributed more to the growth and which contributed less?

4. Can competitor companies easily adopt the impacting organisational strategies implemented by the Chinese multinational contractor firms?

\section{LITERATURE REVIEW}

According to Fairholm (2009) and Goldman, Scott and Follman (2015), organisational strategies are a set of actions, implemented by companies that can lead to the conquest of long-term goals. Based on the desires of the main stakeholders of a company, its top management develops and implements grand strategies and actions that mould the development and implementation of smaller, 
more manageable, controllable strategies under the responsibility of lower level managers. By completing the set targets of the smaller strategies, the company knows that it is on the right path, a step at a time, to achieve its long-term goals.

Sustainable organisational strategies can be defined as long-term actions, implemented by an organisation, with the main goal of guaranteeing positive results in the social, environmental and economic agendas of a company. Critical variables and strategies were selected and identified by Cheah, Kang and Chew (2007), which increase the competitive advantage of Chinese contractors operating in the Chinese market. They found that the following characteristics are significant to increase the local contractor's competitive advantage:

1. Differentiation and market/product diversification as organisational strategies.

2. Financial capabilities, technological/innovative capabilities and relationships with the government, financial bodies, clients and subcontractors, as organisational resources and competencies.

Strategies, risk management procedures, intentions and perspectives of large CCMCs operating in Africa are analysed by Chen et al. (2007). He found that the distinguished strengths of these firms are the price attractiveness resulting from access to low-priced capital, low-cost labour, access to low-priced, quality construction materials and political sustenance from the Chinese capital tunnelled through effective communication. This study will compare if the findings from Chen et al. (2007) have a direct relationship with the CMCCs analysed.

Lu et al. (2013) study how the CMCCs perceive innovation in procurement and if a relation exists between this fact and the CMCCs recent success in the foreign construction market. The authors found that CMCCs are adopting, gradually, innovation in procurement as an organisational strategy.

Competitive advantage of a construction contractor firm can be defined as relative attractiveness the firm often reflected in better income over costs compared to competitors or better value or services from customers' perspective (Rumelt, 2003).

The market positioning and segmentation of local Taiwanese contractors were studied by Pan and Lee (2017). They discovered that the strategic grouping of construction companies and market segmentation are embodied in the contractors' capability, the customer's perception and the competitor's involvement. Several demand conditions of the local market are also identified. Other verdicts include:

1. A favourable image of the company, lower land and fund obtaining cost, the implementation of a product differentiation strategy lead to competitive advantage.

2. Connection development with potential clients and suppliers lead to competitive advantage.

3. Overlaps in activities and material waste neglect lead to competitive disadvantage. 
Types of linkages between a productivity increase of local contractors from singapore and organisational learning in labour efficiency initiatives are researched by Pheng, Shang and Foong (2016). They revealed that organisational learning originates increases in construction productivity. This study will investigate if the CMCCs studied adopted a similar organisational strategy and if it had a positive impact on their performance.

Mwangi (2011) investigated the strategies that Kenyan local firms and European firms can implement in their operation in Kenya to gain a competitive advantage towards Chinese multinationals that have strongly rooted themselves in the country. The author suggests that European firms should compel the Kenyan government to combat corruption and adhere to outstanding good governance and anti-corruption policies, thus eliminating unfair competition and contributing to the countries overall growth.

Lan (2011) studies in detail the expansion of Chinese contractor firms (CCFs) from 1950 to 2008. The study acknowledges the dominance of CCFs in the global market from 2002 onwards, especially in the Asian and African markets. The study verified that the Chinese government had a major role in the success of the Chinese expansion with the implementation, in 1978, of the open-door policies and with the financial and political empowerment of CCFs in the host countries. The author also identified several organisational strategies implemented by the CCFs, which led to their global dominance, such as preferring to be supplied by the local Chinese market, in regards to highly skilled and cheap manpower, construction equipment as well as construction materials (Low, Jiang and Leong, 2004).

Low and Jiang (2003) review the competitive leads that international Chinese contractors hold, focusing on the issues that are negatively contributing to their growth in international markets. The authors identified a unique organisational strategy of implementing synergies with the Chinese government and other Chinese firms, regarding financing and cost control. They also identify that project management capabilities are fragile in the international Chinese contractors studied.

The fields of study related with this research project are as follows:

1. Organisational strategies in contractors (international and local).

2. Organisational strategies in CMCCs (international and local).

3. Market dominance and project's backlog of CMCCs in the Southern African region.

4. The construction industry of Southern Africa and its associated environments.

5. Organisational factors that increase contractors' competitive advantage.

By comparing the results of the literature review analysis with the aforementioned fields of knowledge, a summary was developed and provided in Table 1. 


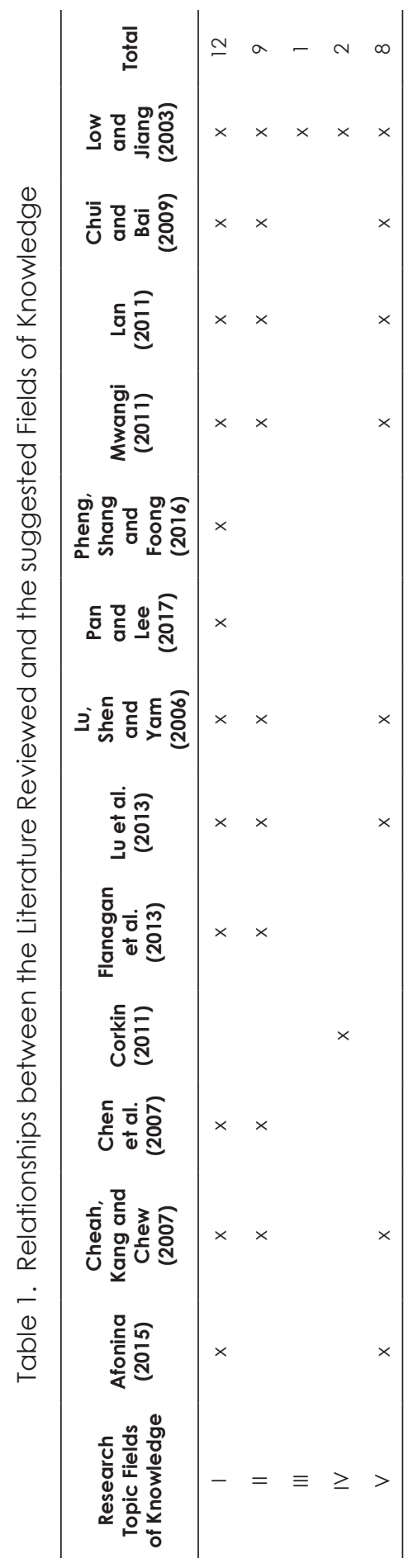


It can be verified, by analysing the table, that organisational strategies in contractors and CMCCs are the knowledge fields that have been studied the most. At the other end of the scale, market dominance and project's backlog of CMCCs in the Southern African region, as well as the construction industry of Southern Africa and its associated environments are the knowledge fields which have been less studied.

However, it is significant to highlight that neither of the literature addresses a set of organisational strategies related with CMCCs in the Southern African region. Therefore, these are the main knowledge gaps that this study is goal-set to complement.

The strategic management tools which increased the performance of check contractors, researched by Afonina (2015), indicated that the usage of similar tools can be contributing to the recent success of CMCCs in the Southern African region. Cheah, Kang and Chew (2007) identify potential Chinese contractors as case studies and identifies results from organisational strategies that lead to competitive advantage in large Chinese contractors.

The identification of the creation, development and implementation of procurement in Chinese contractors' scope of services as an organisational strategy, by Lu et al. (2013), is a major contribution to this study.

Chui and Bai (2009) major findings regarding the similarities and differences of the general conditions of construction contracts between American based contracts and Chinese based contracts inform that local Chinese contractors are used to perform under international best practices, which, is an indication that they can compete at the same level, with western big players in the global construction market.

Low and Jiang (2003) history of the Chinese contractors' entry in the market of Africa is a great starting point for this research. The authors also identify organisational strategies, weaknesses and strengths of CMCCs that this research will contemplate and verify if they are applicable to the Southern Africa operating contractors.

\section{RESEARCH METHODOLOGY}

A mixed research methodology was chosen, drawing upon both positivist and constructionist epistemologies as well as qualitative and quantitative data. Local knowledge, theory first, cross-sectional study and falsification (Onwuegbuzie and Teddlie, 2003; Creswell, 2011) are other process choices which were used to analyse the collected data.

A clear, concise and thorough data collection method with the support of tools, such as TiMetric (2018) platform and Survey Monkey (2017), was chosen, explained and developed to compose the research method. Primary, secondary as well as qualitative and quantitative types of data were chosen to be collected and analysed, through an archival and online questionnaire survey, contributing to the characterisation of the chosen approach to the research design.

The method for data analysis used in this study consisted of a sequential relationship examination of data analysis tools and strategies to effectively analyse and draw conclusions from qualitative and quantitative types of previously collected data (Williams, 2007; Onwuegbuzie and Teddlie, 2003). To effectively analyse the data, six distinct tools and strategies were utilised, overall. 
Constructionist and positivist epistemologies were utilised in the methodology of research resulting, globally, in a mixed research process with quantitative and qualitative methods (Morse, 2003).

Subquestions 1 and 2 were answered by archival research, highly qualitative in nature. A detached and mild constructionist epistemology was utilised in the format of a literature review, historic survey and environmental scan (Altheide and Johnson, 2011).

Regarding Subquestions 3 and 4, the verdicts attained from the data collection and its analysis, aligned with the findings related to Questions 1 and 2, served as a substance to elaborate an engaged factual survey research, with an involved and mild positivist epistemology, highly quantitative in nature, in the format of an online questionnaire.

The following figure highlights the main features of the research methodology as well as the question(s) of the research interrelationships.

\section{Mixed Research Methodology}

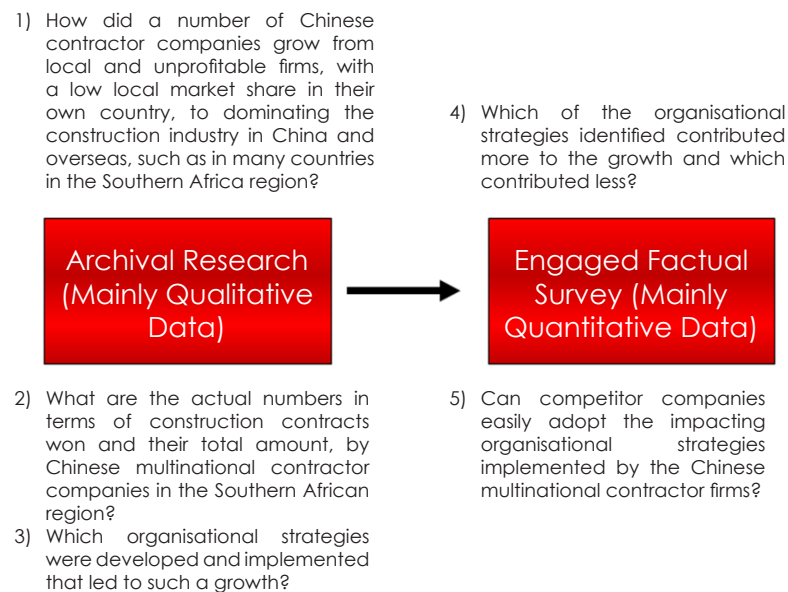

2) What are the actual numbers in terms of construction contracts won and their total amount, by Chinese multinational contractor companies in the Southern African region?

3) Which organisational strategies were developed and implemented that led to such a growth?

4) Which of the organisational strategies identified contributed more to the growth and which contributed less?

5) Can competitor companies easily adopt the impacting organisational strategies implemented by the Chinese multinational contractor firms?

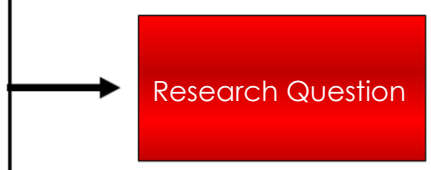

Which are the organisational strategies, adopted by Chinese multinational contractor firms, that contributed most to their success in the Southern African market and can they be easily implemented by competitors?

Figure 1. Considered Methodology of the Research and the Question(s) of the Research Interrelationships

\section{Population}

The sampling technique consisted of a quota sampling (Berinsky, 2006; Turner, 2003; Yang and Banamah, 2014), where 100 invitations to pre-selected participants were sent (e-mail) and a link to access the online questionnaire survey was shared.

The pre-selected participants consisted of a list of contacts of experienced professionals that are currently working or have recently worked in organisations of the Southern African construction industry, such as contractors, consultants, financial institutions, public and private construction project implementers. 
The survey link was opened between the 19th and 27th of March of 2018 and 44 participants successfully completed in total the questions of the survey, establishing a response rate of $44 \%$, which is an acceptable percentage for the type of survey chosen, according to Kotzé (2007) and Hibberts, Johnson and Hudson (2012). The following graphics summarise the main features of the 44 participants.

Also, important to mention, is that the respondents hold, as per the statistics shown, academic degrees (Bachelor of Science and Master of Science degrees as an average) and are presently exercising management and top management functions in their actual organisations, which makes them qualified to comment and answer organisational strategy based questions.

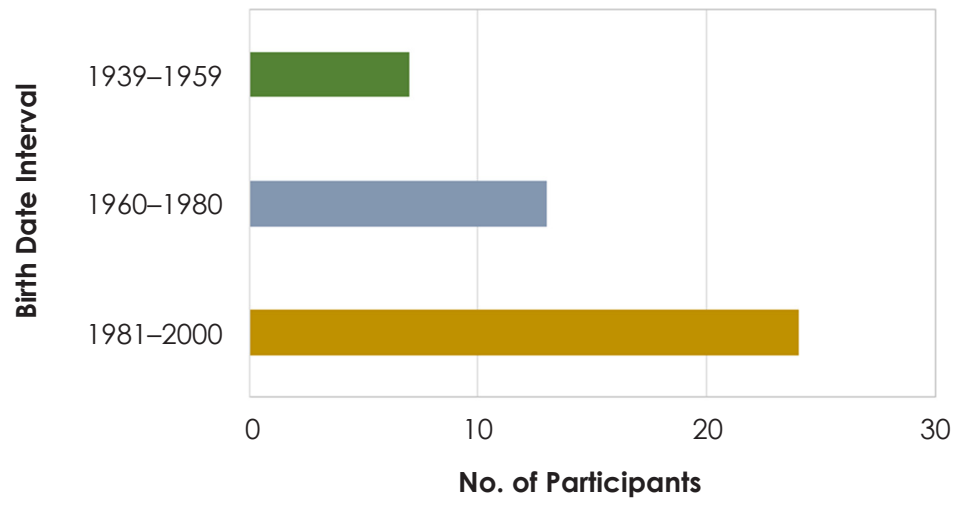

Figure 2. Participant Characteristic 1: Birth Date Interval (44 Answers/0 Skips)

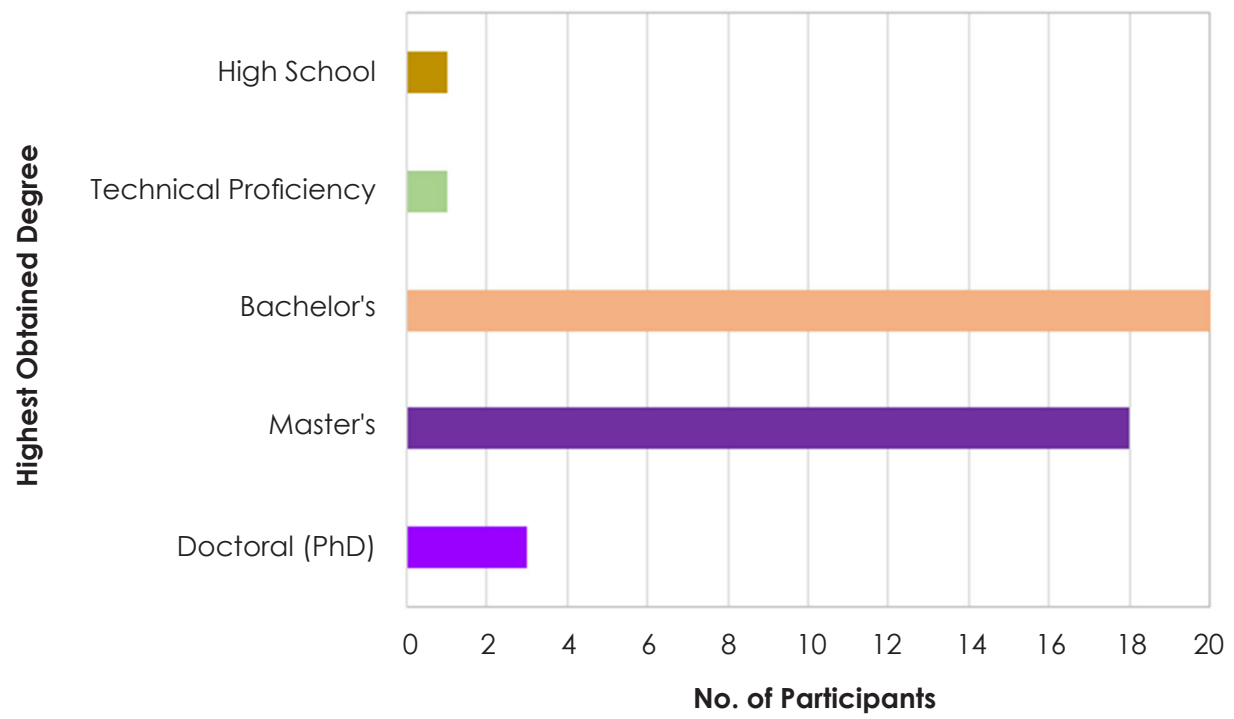

Figure 3. Participant Characteristic 2: Highest Obtained Academic Degree (43 Answers/l Skip) 


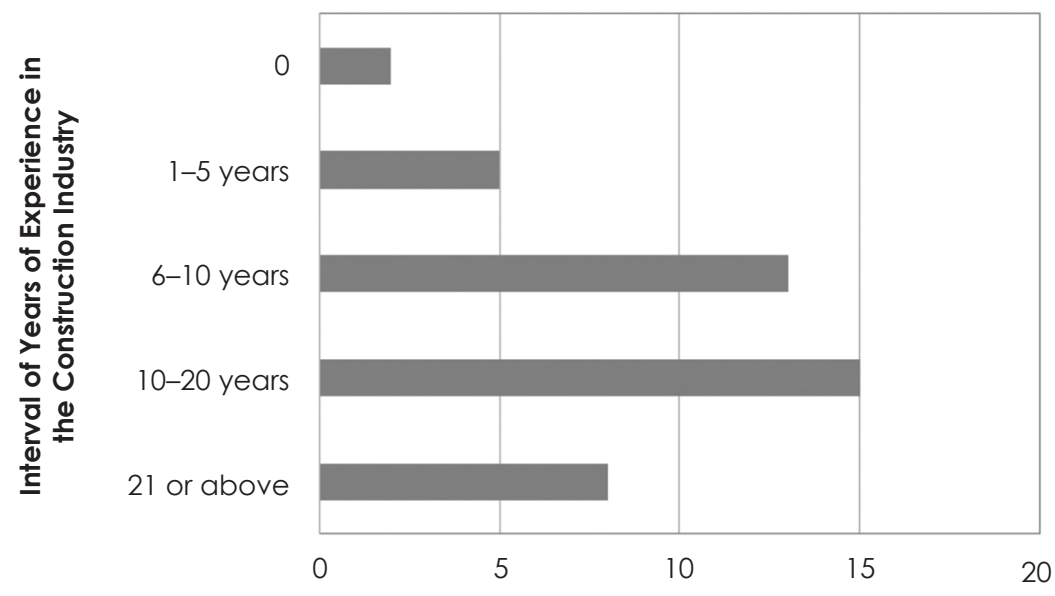

No. of Participants

Figure 4. Participant Characteristic 3: Working Experience Years in the Construction Industry (43 Answers/1 Skip)

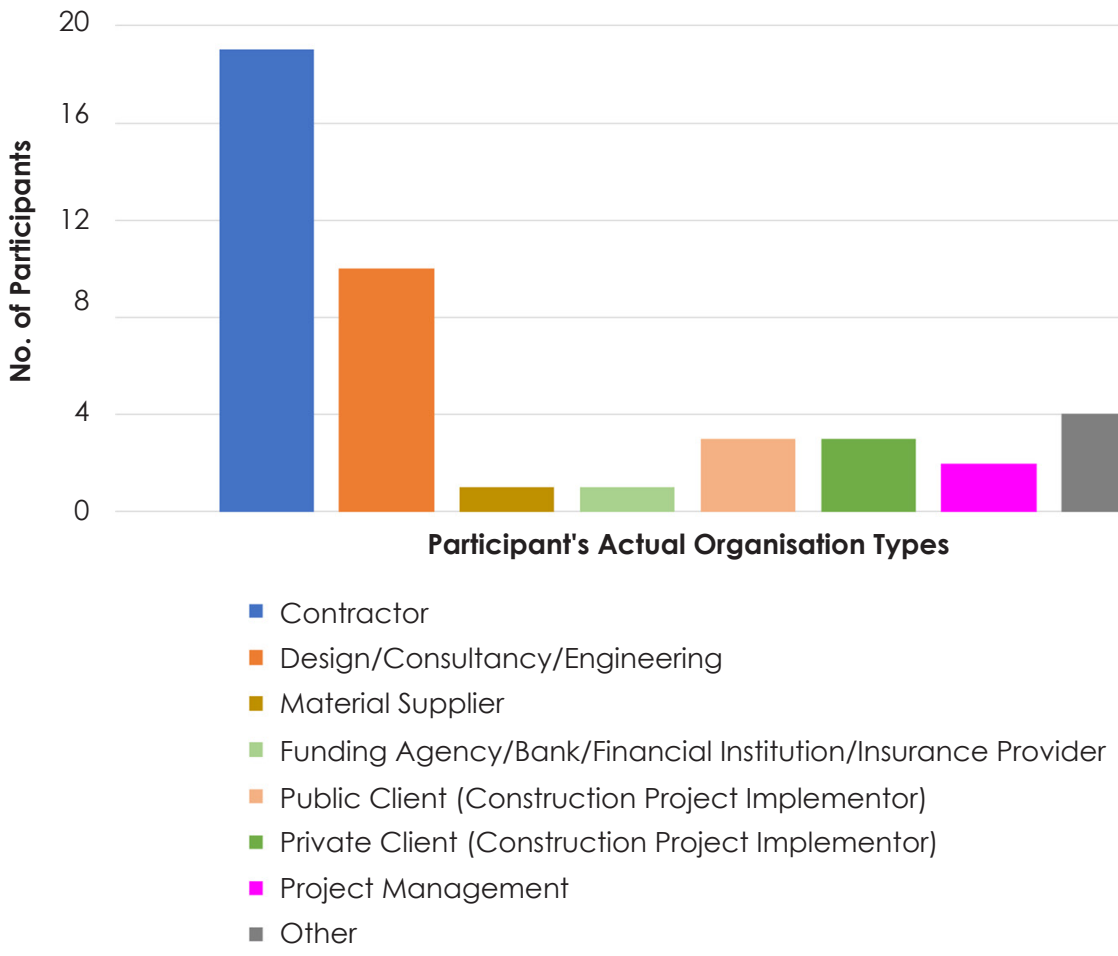

Figure 5. Participant Characteristic 4: Actual Participant Organisation Types (43 Answers/1 Skip) 


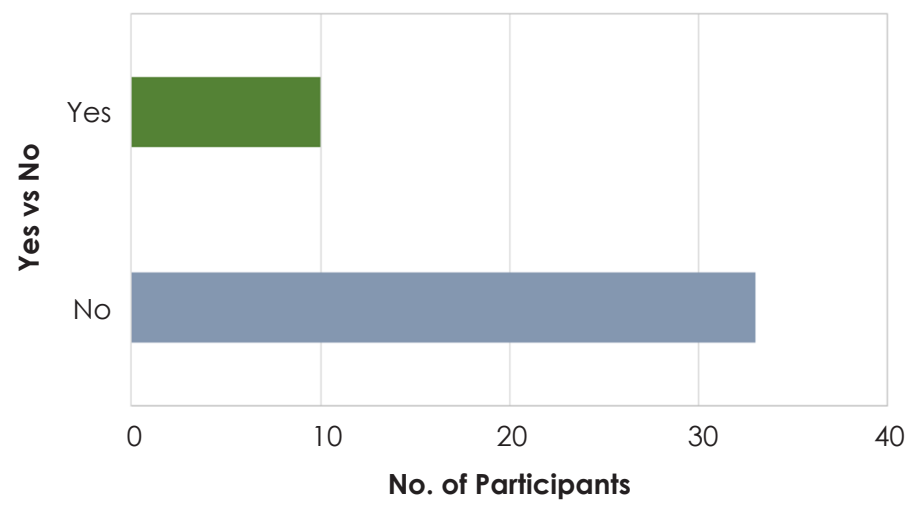

Figure 6. Participant Characteristic 5: Experience in Working for a Chinese Contractor Company (43 Answers/1 Skip; Yes = Directly Associated and No = Only Indirectly)

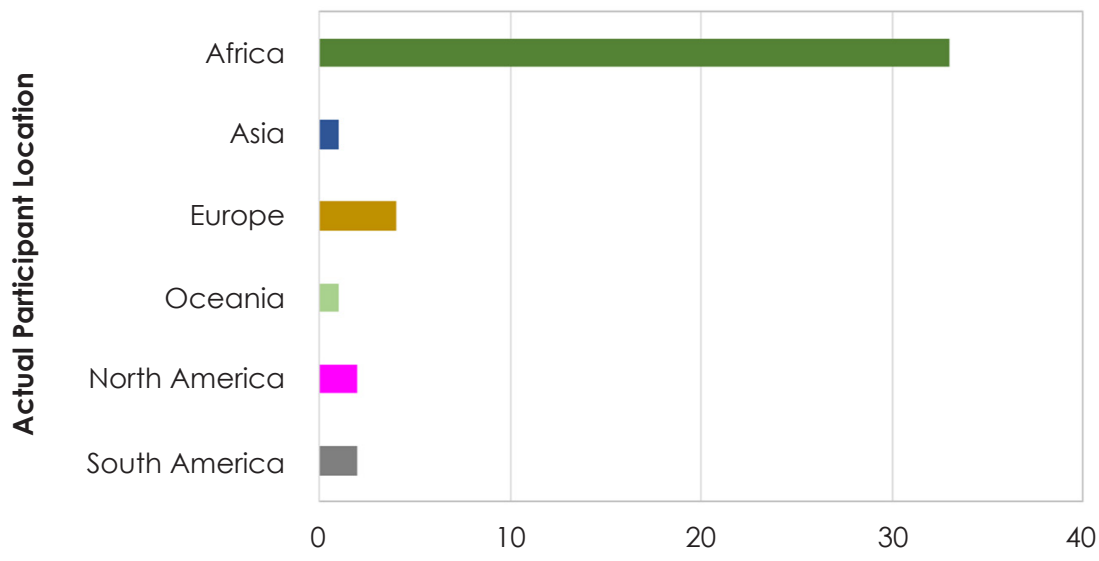

No. of Participants

Figure 7. Participant Characteristic 6: Actual Participant Location (43 Answers/ 1 Skip)

\section{Research Materials and Instruments}

The research focused on:

1. Governmental documents to perform an environmental scan of the construction markets studied.

2. ENR's database and TiMetric's platform (TiMetric, 2018) to identify well established Chinese multinational contractors operating in the region studied. 
3. The identified Chinese multinational contractor's profiles and annual reports to identify organisational strategies that increase competitive advantage.

4. Journal articles and academic thesis to identify general organisational strategies that lead to competitive advantage in the construction industry.

5. Survey Monkey platform to prepare and send an online survey questionnaire, as well as collect and analyse quantitative data.

\section{Data Collection}

The data collection of this research began simultaneously with:

1. a literature review, focusing on identifying and organisational strategies that contribute to an increase in competitive advantage in contractor firms,

2. a historical review focusing on the period when CCFs began to invest in operations outside of China and the exterior environmental factors that contributed to the expansion and

3. an archival review focusing on the Southern African construction markets with the main goal of identifying which Chinese multinational contractor firms have won the biggest backlog in construction projects, from 2004 to the present.

For the previous mentioned steps, journal articles and TiMetric (2018) platform were used. Primary and secondary data sources (Johnson and Turner, 2003; Johnston, 2014) were consulted and qualitative and quantitative data was collected.

The analyses of the annual company financial reports and policies of the distinguished CMCCs identified, as well as the organisational strategies by them implemented and crosschecking this data with the data obtained from the historical and literature review was the following, highly qualitative, step of the research methodology. The explained sequence allowed to identify and shortlist the most relevant organisational strategies implemented, which directly influenced the CMCCs success in dominating the market of construction in Southern Africa. The chosen methods and tools of data collection, used in this study, are as shown in Figure 8. 


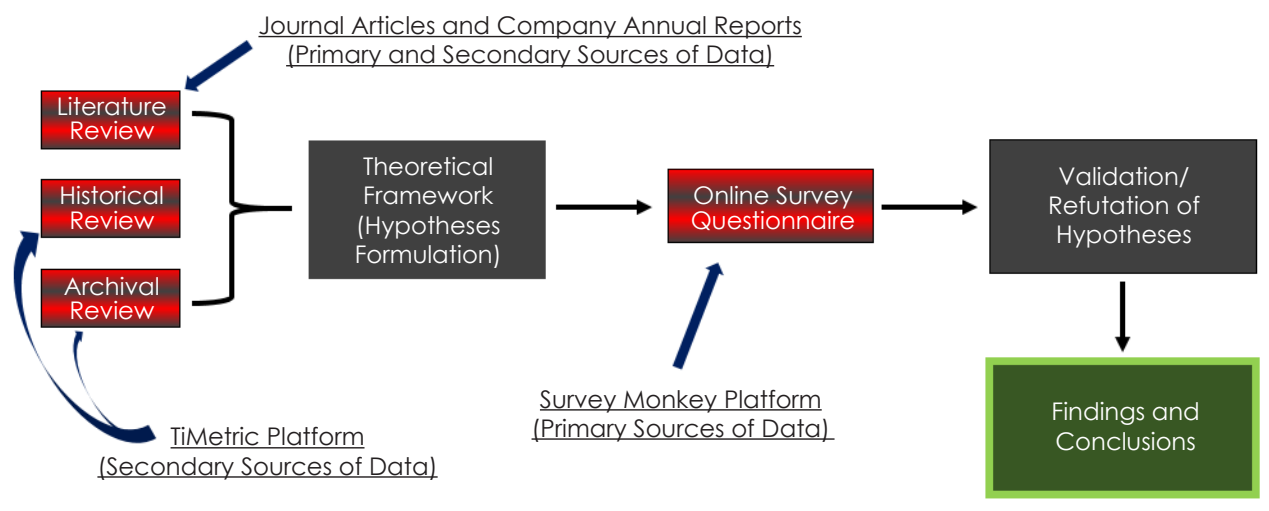

Figure 8. Diagram of the Selected Method and Tools of Data Collection

\section{DATA ANALYSIS}

The first step was the identification of the most successful CMCCs operating in the Southern African region, employing a historical review and archival review. Both reviews resulted in data collection with qualitative attributes. This part of the study considered a grounded theory qualitative analysis (Dey, 2005; Erickson, 2011) to identify CMCCs operating in the Southern African region. Then, a multivariate explanatory (three variables) quantitative comparison, in conjunction with a data tabulation technique, on the number of contracts won and the total value of the contracts shortlisted the most successful CMCCs operating in the mentioned region (most contracts won and higher contract value) (Easterby-Smith, Thorpe and Jackson, 2012; Larson-Hall and Plonsky, 2015; Sullivan and Artino, 2013).

The following step, with the most successful Chinese contractors and with organisational strategies identified, in Step 1 and Step 2 (literature review), respectively, consisted in the analysis of CMCCs' organisational annual reports and other documentation, aiming at finding relationships between the data found in the literature review (qualitative) and the data found in the company documents (qualitative and quantitative), intending to shortlist significant organisational strategies. Sequentially, a content (Easterby-Smith, Thorpe and Jackson, 2012; Dey, 2005) and framework analysis (Berg, 2001; Gale et al., 2013) were used jointly to produce effective findings. The qualitative data obtained from this section of the research supported the development of the questionnaire survey, absorbed in collecting quantitative data to complement the qualitative findings obtained and adding more value to the study.

The highlights and summary of the data analysis conducted, as well as the existing relationships between the research question, methodology and methods are shown in Figure 9. 


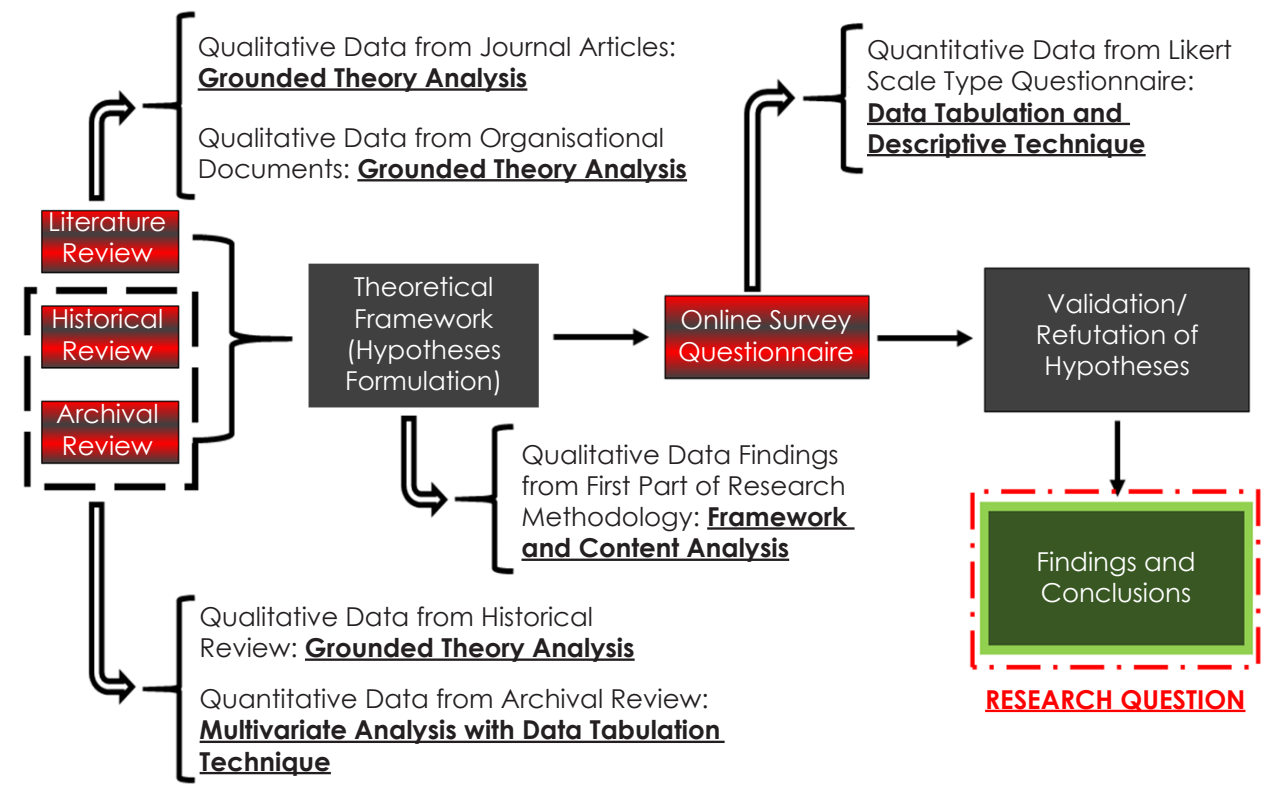

Figure 9. Data Analysis Method and the Existing Relationships between Research Question, Methodology and Methods

\begin{tabular}{|c|c|c|}
\hline DATA COLLCCTION STAGE & QUALITATIVE DATA & QUANTITATIVE DATA \\
\hline $\begin{array}{c}\text { Literature } \\
\text { Review }\end{array}$ & NOT APPLICABLE \\
\hline $\begin{array}{c}\text { Historical } \\
\text { Review }\end{array}$ \\
$\begin{array}{c}\text { Archival } \\
\text { Review }\end{array}$
\end{tabular}

Figure 10. Considered Types of Data Presentation

\section{ASSURANCE OF ETHICS}

Prior to the data collection commencement stage, the research obtained ethical approval from the University of Roehampton. All data obtained were either from published and public literature, paid data centres (ENR and TiMetric), private corporations with the previous consent or from voluntary online questionnaire participants. Guaranteeing the anonymity of the respondents of the online 
questionnaire is assured with the utilisation of Survey Monkey (2017) software, where the researcher never knows the respondent's identity. Nonetheless, it is also significant to refer that before the commencement of this data collection method by the researcher, by attaching an explanatory letter to the questionnaire, the researcher has:

1. Obtained unanimous voluntary participation.

2. Informed the purpose of the research.

3. Advised on the rights and responsibilities of the participants.

4. Informed about the benefits and the risks of the participants' inputs.

5. Informed that the participant could withdraw its responses at any time.

All data collected was efficiently archived in a secure location, in the original format, until the research evaluation stage concludes, as suggested by Bannister (2007).

\section{FINDINGS, ANALYSIS AND EVALUATION}

Angola and Tanzania are the countries where the success of Chinese contractors is most relevant, mainly due to the facts that they are the countries with bigger land area, bigger need for new infrastructure to galvanise their development, bigger population, are ranked second and third in terms of gross domestic product (GDP) (which indirectly contributes to their capability to receive foreign loans).

On the other end of the scale, Malawi, Madagascar, Swaziland and Lesotho are the countries where the Chinese contractors have had the least success. This can be explained due to their size (land area and population) and fewer needs regarding new infrastructure. Simultaneously, these are countries with low GDP, therefore, with low capability to receive foreign loans and less interesting to convince foreign investment. No data was obtained for the smallest island countries - Mauritius and Seychelles.

The companies that are present in most countries and that have a higher number of contracts in backlog are listed as follows (TiMetric, 2018):

1. China State Construction Engineering Corporation Ltd. (CSCEC).

2. China Communications Construction Group Ltd. (CCCC).

3. Power Construction Corporation of China (PCCC).

4. China Railway Group Ltd. (CRG).

5. China Railway Construction Corporation Ltd. (CRCC).

6. China Energy Engineering Corporation Ltd. (CEEC).

7. China National Machinery Industry Corporation (CNMIC).

8. Beijing Construction Engineering Group (BCEG).

9. Anhui Foreign Economic Construction (Group) Co. Ltd. (AFEC).

10. China Geo-Engineering Corporation (CGEC).

11. China Henan International Cooperation Group Co. Ltd. (CHICO). 
Table 2 compares the identified contractor companies' ranking in the ENR List of Top 250 International Contractors, from 2010 onwards.

Table 2. Ranking of the Identified Chinese Multinational Contractor Companies in the ENR List of Top 250 International Contractors List

\begin{tabular}{lrrrrrrrr}
\hline \multirow{2}{*}{ Organisation } & \multicolumn{8}{c}{ Year } \\
\cline { 2 - 9 } & $\mathbf{2 0 1 0}$ & $\mathbf{2 0 1 1}$ & $\mathbf{2 0 1 2}$ & $\mathbf{2 0 1 3}$ & $\mathbf{2 0 1 4}$ & $\mathbf{2 0 1 5}$ & $\mathbf{2 0 1 6}$ & $\mathbf{2 0 1 7}$ \\
\hline CSCEC & 22 & 20 & 22 & 24 & 20 & 17 & 14 & 11 \\
CCCC & 13 & 11 & 10 & 10 & 9 & 5 & 3 & 3 \\
PCCC & 41 & 24 & 23 & 20 & 23 & 11 & 11 & 10 \\
CRG & 53 & 33 & 39 & 34 & 28 & 23 & 20 & 21 \\
CRCC & 25 & 29 & 30 & 53 & 71 & 47 & 55 & 23 \\
CEEC & 84 & 71 & 62 & 56 & 51 & 44 & - & 27 \\
CNMIC & 26 & 26 & 24 & 25 & 25 & 27 & 23 & 31 \\
BCEG & 117 & 113 & 146 & 133 & 128 & 109 & 115 & 142 \\
AFEC & 179 & 155 & 171 & 151 & 158 & 153 & 145 & 116 \\
CGEC & 106 & 129 & 127 & 110 & 124 & 120 & 124 & 126 \\
CHICO & 159 & 154 & 151 & 147 & 140 & 113 & 130 & 150 \\
\hline
\end{tabular}

Source: Tulacz and Reina (2010-2017)

It can be concluded that all of the identified CCFs are well ranked internationally, meaning that they are also being successful in other regions of the globe. The strongest of the group has been CCCC, with a top 10 rank since 2012. It can also be verified that a growth tendency (translated in the rank position of each firm, each passing year) also exists.

\section{Shortlisted Organisational Strategies}

By crosschecking the organisational strategies identified in the literature review with the organisational strategies identified in the most successful multinational Chinese contractor companies, it was possible to shortlist the 10 organisational strategies that, theoretically, have more to contribute to the recent success of Chinese contractor companies in Southern Africa, as follows:

1. Capability to offer a lower price for construction services.

2. Long-term partnerships with low-cost equipment and material suppliers.

3. Easy access to loans and funds from the organisation's home government.

4. Fragile adherence to compliance and anti-corruption policies.

5. Training and development of human resources from the organisation's home country. 
6. Training and development of human resources from the organisation's host country.

7. Capability to trade debt for local resources, such as wood, land and minerals.

8. Capability to offer all types of technical, construction associated services and funding options to their clients.

9. Capability to offer and deliver all types of contract agreements to their clients, including construction/design and build (or design and construction)/engineering, procurement and construction (EPC)/build, operate and transfer.

10. Creation of dedicated and specialised sub-companies.

Each of the shortlisted organisational strategies is explained in detail in the following sub-section.

\section{Capability to Offer a Lower Price for Construction Services}

The myriad of resources offered by China, such as the available quantity of qualified workforce (effective and efficient education system), diversity of existing construction materials and equipment, allows Chinese contractor companies, to hire qualified personnel, quality services, quality materials and equipment at a lower cost than other competitors from overseas. Chinese labour (mostly rural dwellers, entire villages in remote areas of China are recruited for this purpose) instead of locals. This factor is, undoubtedly, the major contributor to their low-cost strategy.

\section{Long-Term Partnerships with Low-Cost Equipment and Material Suppliers}

China has a vast list of contractor companies established and even a wider list of equipment and material suppliers. Overall, the equipment and material acquisition cost are lower in China than in the rest of the world. The same can be said about the rental cost of construction equipment.

Local Chinese contractors have established serious relationships with equipment and material suppliers from China and have counted on them for their works abroad. These serious relationships allow for discount prices, less bureaucracy, availability of stock and less investment risk, contributing in general to a lower operational cost and quicker procurement and logistics process, that, overall, increase the Chinese contractor multinational company competitive advantage.

\section{Easy Access to Loans and Funds from the Organisation's Home Government}

Financial institutions such as export-import bank, China export and credit insurance corporation, also known as Sinosure and the Chinese Development Bank are stateowned enterprises that have, over the past five years, financed more construction projects than any other renowned credit exporting agency worldwide. The same applies to the Southern African market where all of the most successful Chinese contractor companies identified have actual projects financed by these Chinese export credit agencies. 
This partnership allows for the Chinese contractor companies to win tender's for construction projects more easily, by offering the project finance option to the project's clients. The mentioned Export Credit Agency's (ECA) offer a smooth payment method with the lowest interest rates available, which are very attractive aspects for any client, at the same time that it boosts the competitive advantage of CCFs.

With this partnership, the Chinese government contributes immensely to the growth of its Chinese contractors and other construction-related services provider, at the same time that it galvanises the Chinese economy (practically the funds never leave China and the ECA's requires that all material, services and equipment must be of Chinese origin and exported from there).

\section{Low Adherence to Compliance and Anti-Corruption Policies}

The compliance and anti-corruption policies of the identified successful Chinese contractor companies are vague or even none existing in some cases when compared to the other contractor companies. This fact positively contributes to the operation of Chinese contractor companies in working with clients that are not eligible to most of the occidental contractor companies. An actual example can be verified in the Chinese market dominance in Angola, one of the most corrupted and less transparent countries in the world, where the majority of the public and private clients do not qualify, in terms of due diligence, in the occidental contractor's internal compliance and good governance policies. However, it is the country where the identified successful Chinese contractor companies have most contracts underway and have contracts at a high contract price.

\section{Investment in Human Resource Training from the Organisation's Home Country}

Employees are the most important assets of organisations. Satisfied employees focused on providing quality service and solutions for a client's problem or need to strengthen an organisation's competitive position in the market (Gabčanová, 2011). Employees from the organisation's home country have the advantage of being more aligned with the company's and its shareholders' organisational culture, which is the basis of the modus operandi of any organisation. Thus, they are also more capable of transferring the organisational values and culture to other locations of the globe (Kinnie et al., 2005).

The research revealed that the identified Chinese contractors invest in Chinese employees development and training (technical, core, management and interpersonal skills), however, a well-structured performance management system is not implemented in all. Overall, when compared to competitors with origin in other countries (e.g., European, Japanese and United States of America), it is clear that this organisational strategy is considered a minor priority in Chinese contractors.

\section{Investment in Human Resource Training from the Organisation's Host Country}

Employees from the organisations' host country contribute to the diversity of the workforce. It is this diversity that enables organisations to be more capable to address business issues related to new, strange and highly competitive environments, such as the construction industry of Southern Africa, for Chinese contractors. Not only 
from the contribution of local knowledge, contacts of interest and the identification of particular singularities but also from the cultural difference that allows the foreign organisation to better adapt itself to the local conditions (Noon, 2007).

The research revealed that the identified Chinese contractors invest in local employees development and training (technical, core, management and interpersonal skills), however, the level of investment in training and development and the strategic intent to do so is lower when compared to the Chinese workforce.

\section{Capability to Trade Debt for Local Resources, Such As Wood, Land and Minerals}

Unlike the majority of the occidental contractor companies, the identified Chinese contractors working successfully in the Southern African market have flexibility in receiving the payment for their services. Areas of land, valuable and not so valuable materials, licenses to open other businesses, wood, among others, are all accepted by them as trade currencies. This flexibility allows Chinese contractor companies to offer their services to public and private entities that may not have the cash flow available for the due payments but have another valuable to trade. The synergy that exists with the Chinese government and with other Chinese companies of other sectors, converts this type of trades to sustainable ones.

As an example, in Mozambique, $\mathrm{CHICO}$ in the contract related to the engineering procurement and construction of highways in the north of the country, as accepted to be paid in land ownership and wood exploration licenses.

\section{Capability to Offer All Types of Technical, Construction Associated Services and Funding Options to Their Clients}

As noted by Cheah, Kang and Chew (2007) and Chen et al. (2007), Chinese contractors evolved from a mere contractor labour service provider to a more proficient organisation, capable of delivering all types of technical solutions to the projects they are involved in. Such solutions include geotechnical surveys and studies, topography, bathymetry, design, procurement, logistics, all types of construction services, quality control and assurance, project management, and training. With this range of capabilities, they are able to participate in several tender processes, at the same time and equal, in terms of capability, other big competitors of the industry, not losing competitive advantage.

\section{Capability to Offer and Deliver All Types of Contract Agreements to Their Clients, Including Construction/Design and Build (or Design and Construction)/EPC/Build, Operate and Transfer}

Mainly due to their history in China, it was verified that all of the identified Chinese contractors have proven capability to deliver a vast range of project solutions to their clients. 


\section{Creation of Dedicated and Specialised Sub-Companies}

The organisational strategy of creating a subsidiary company consists of creating a separate legal business controlled by the parent organisation, which has several advantages (Ghahroudi, 2011), such as:

1. Risk isolation and control: The parent company and the subsidiary are two separate legal entities. As such, the losses or debt of a subsidiary does not automatically transfer to a parent company (Lo, Mahoney and Tan, 2011).

2. Increase in operational flexibility and efficiency: Actions in the subsidiary do not need to wait for approvals of the senior management of the parent company, saving time and procedural costs (Birkinshaw, Hood and Jonsson, 1998).

3. Presence abroad: A foreign subsidiary offers the parent company an international presence, which contributes to an expansion of reach, with new market opportunities and new clients (Birkinshaw, Hood and Jonsson, 1998).

4. Limited liability: In the case of a problem that affects the image of a subsidiary (i.e. labour safety and health issues), especially if the subsidiary and the parent company have different names, the image of the parent company is not affected (Ghahroudi, 2011).

5. Decreased costs: A myriad of organisations prefer to acquire foreign subsidiaries in regions where the costs associated with labour and production are inferior to those in their home countries. This allows organisations to provide their services at lower costs, contributing to a higher profit generation (Lo, Mahoney and Tan, 2011).

The research revealed that all identified Chinese multinational contractors adopt the subsidiary creation strategy. As an example, CCCC, which is the topranked Chinese multinational contractor (Tulacz and Reina, 2017), has over 60 specialised subsidiaries, as illustrated in Table 3 (Ernest and Young, 2017). 
Table 3. List of Specialised Subsidiary Organisations of CCCC (Parent Company)

1. Beijing Union Real Estate Co. Ltd.

2. Beijing United Development Co. Ltd.

3. CCCC Southwest Investment Co. Ltd.

4. CCCC Asset Management Co.

5. CCCC City Investment Co.

6. CCCC Construction Financial Leasing Co. Ltd.

7. CCCC Dredging Group Co. Ltd.

8. CCCC Electromechanical Engineering Co. Ltd.

9. CCCC First Harbor Consultants Co. Ltd.

10. CCCC First Harbor Engineering Co. Ltd.

11. CCCC First Highway Consultants Co. Ltd.

12. CCCC First Highway Engineering Co. Ltd.

13. CCCC Foshan Rail Transportation Investment Development Co. Ltd.

14. CCCC Fourth Harbor Consultants Co. Ltd.

15. CCCC Fourth Highway Engineering Co. Ltd.

16. CCCC Guongzhou Dredging Co. Ltd.

17. CCCC Haerbin Subway Investment and Construction Co.

18. CCCC Hainan Construction Investment Co. Ltd.

19. CCCC Haixi Investment Co. Ltd.

20. CCCC Highway and Bridge Technology Consultants Co. Ltd.

21. CCCC Highway Consultants Co. Ltd.

22. CCCC Second Highway Engineering Co. Ltd.

23. CCCC Shanghai Dredging Co. Ltd.

24. CCCC Shanghai Equipment Engineering Co. Ltd.

25. CCCC Huadong Investment Co. Ltd.

26. CCCC Investment Co. Ltd.

27. CCCC Investment Fund Management (Beijing) Co. Ltd.

28. CCCC Nansha Investment and Development Co. Ltd.

29. CCCC Newspaper Office Co. Ltd.

30. CCCC Northeast Investment Co. Ltd.

31. CCCC Northwest Investment Co. Ltd.

32. CCCC Railroad Design Co.

33. CCCC Real Estate Co.

34. CCCC Second Harbor Consultants Co. Ltd.

35. CCCC Second Highway Consultants Co. Ltd.

36. CCCC Shenyang Gas and Heat Research and Design Co.
37. CCCC South Investment and Development Co. Ltd.

38. CCCC Tainhe Machinery Manufacturing Co.

39. CCCC Third Harbor Consultants Co. Ltd.

40. CCCC Third Highway Engineering Co. Ltd.

41. CCCC Tianjin Dredging Co. Ltd.

42. CCCC Tunnel Engineering Co. Ltd.

43. CCCC Water Transportation Consultants Co. Ltd.

44. CCCC Xi'an Road Construction Machinery Co. Ltd.

45. CCCC Yunnan Highway Development Co.

46. CCCC Zhuahi Intercity Communications Facilities Investment Co.

47. Chenzhou Road Construction Machinery Factory of China Road Bridge Group (CRBC)

48. China Communications Construction Co. Ltd.

49. China Communications Construction Financial Co. Ltd.

50. China Communications Construction Real Estate Co. Ltd.

51. China Harbour Engineering Co. Ltd.

52. China Highway Engineering Group Corp.

53. China Highway Vehicle and Machinery Co. Ltd.

54. China National Real Estate Development Group Corp.

55. China National Communications Materials and Equipment Corp.

56. China Northeast Gen. Municipal Eng'g Design and Research Institute

57. China Road and Bridge Corp.

58. Chuwa Bussan Co. Ltd.

59. CRBC International Co. Ltd.

60. Facilities Management, Zhong Qiao, Zhongshan, CRBC

61. Guangzhou Port Machinery Industry Corp.

62. Shanghai Zhenhua Port Machinery Co. Ltd.

63. Southwest Municipal Engineering Design and Research Institute of China

64. Tianhe Mechanical Equipment Manufacturing Co. Ltd.

65. Xi'an Road Construction Machinery Factory

66. Zhenhua Engineering Co. (Shenzhen) 
The following diagram in Figure 11 groups and classifies the shortlisted organisational strategies in regards to the financial, legal and technical fields of an organisation.

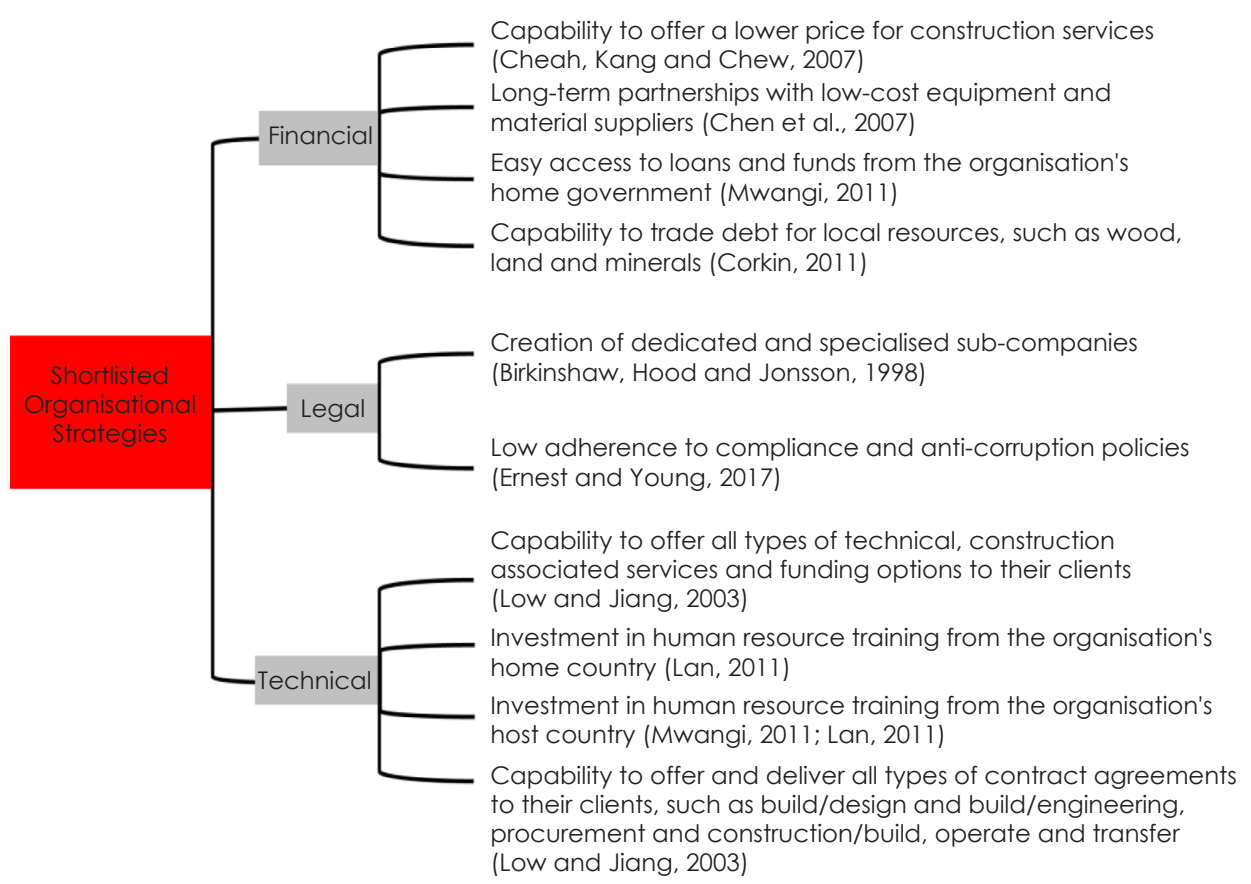

Figure 11. Diagram of Shortlisted Organisational Strategies: Classified and Grouped

\section{Online Questionnaire Survey Results}

Each of the identified organisational strategies was first addressed independently, where the participants ranked between null and 5 (null means "No Influence" and 5 means "Full Influence") the influence that an organisational strategy has in the success of the Chinese contractor companies in Southern Africa.

\section{Independent analysis of the contribution of each organisational strategy to the recent success of Chinese contractor companies operating in the Southern African industry}

In this sub-section, the following Figures 12 to 21 illustrate the results for each of the strategy in this study. 


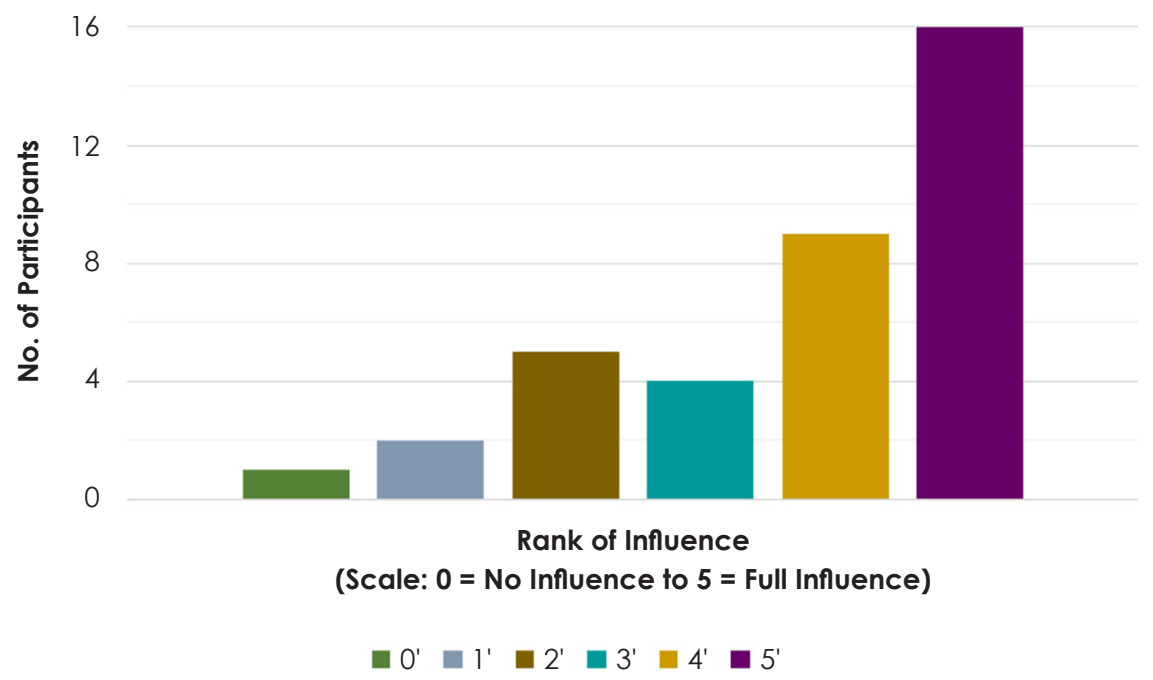

Figure 12. Capability to Offer a Lower Price for Construction Services (37 Answers/ 7 Skips)

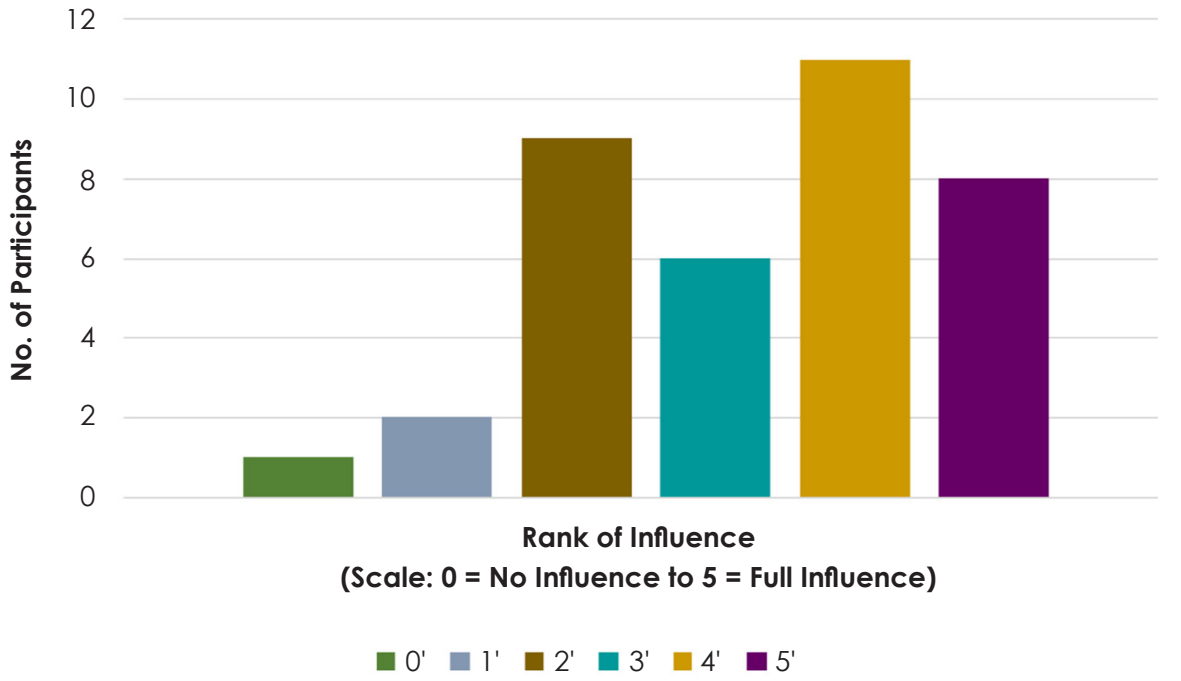

Figure 13. Long-Term Partnerships with Low-Cost Material, Equipment and Service Providers (37 Answers/7 Skips) 
30

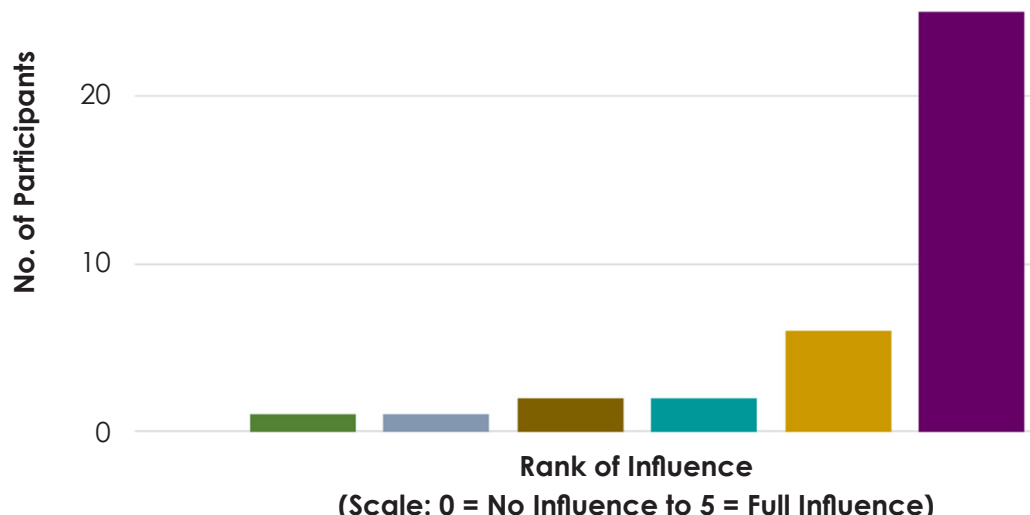

(Scale: $0=$ No Influence to 5 = Full Influence)

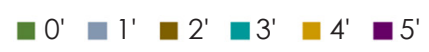

Figure 14. Easy Access to Loans and Funds from the Chinese Government (37 Answers/7 Skips)

10

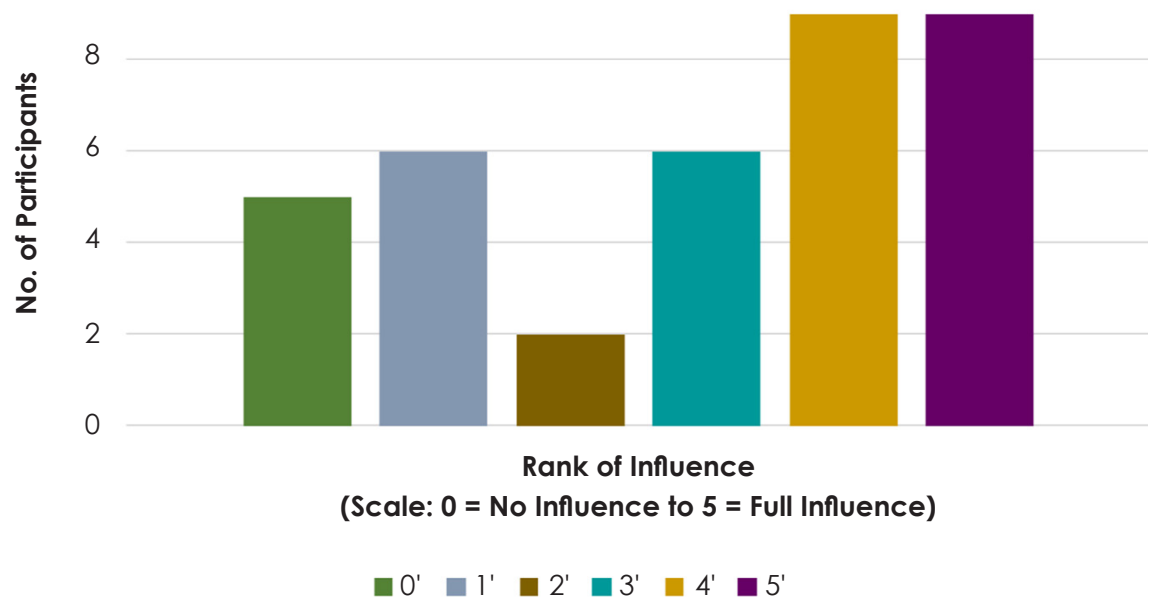

Figure 15. Low Adherence to Internal Compliance and Anti-Corruption Policies (37 Answers/7 Skips) 


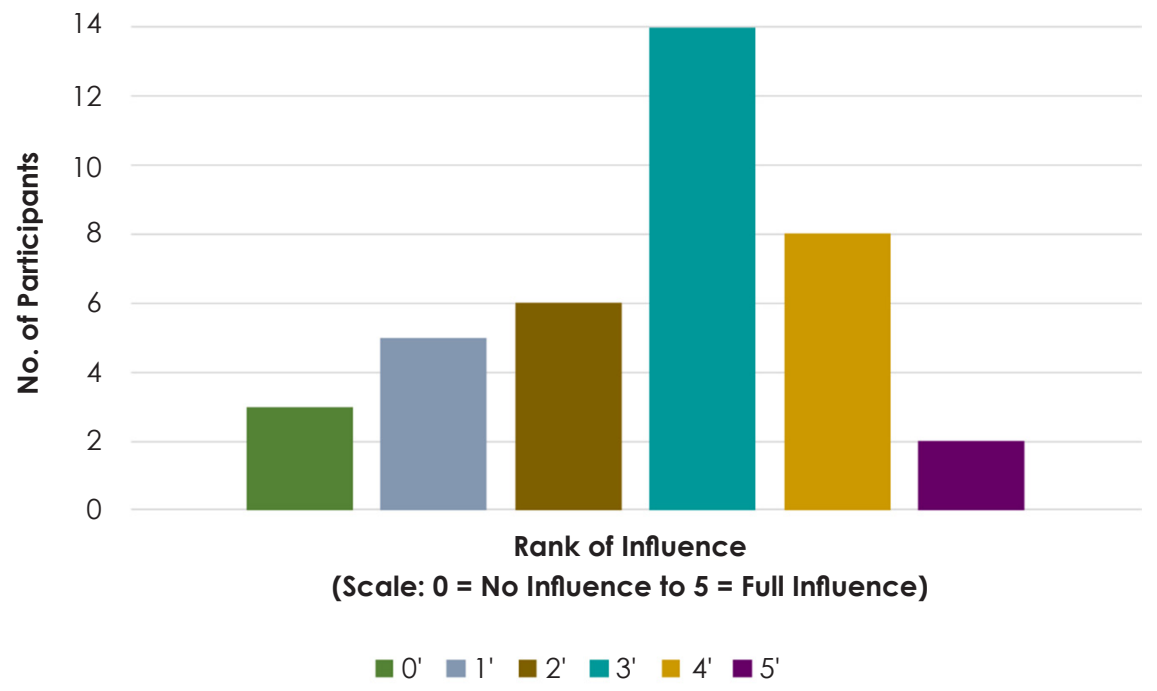

Figure 16. Investment in Chinese Human Resource Training and Development (38 Answers/6 Skips)

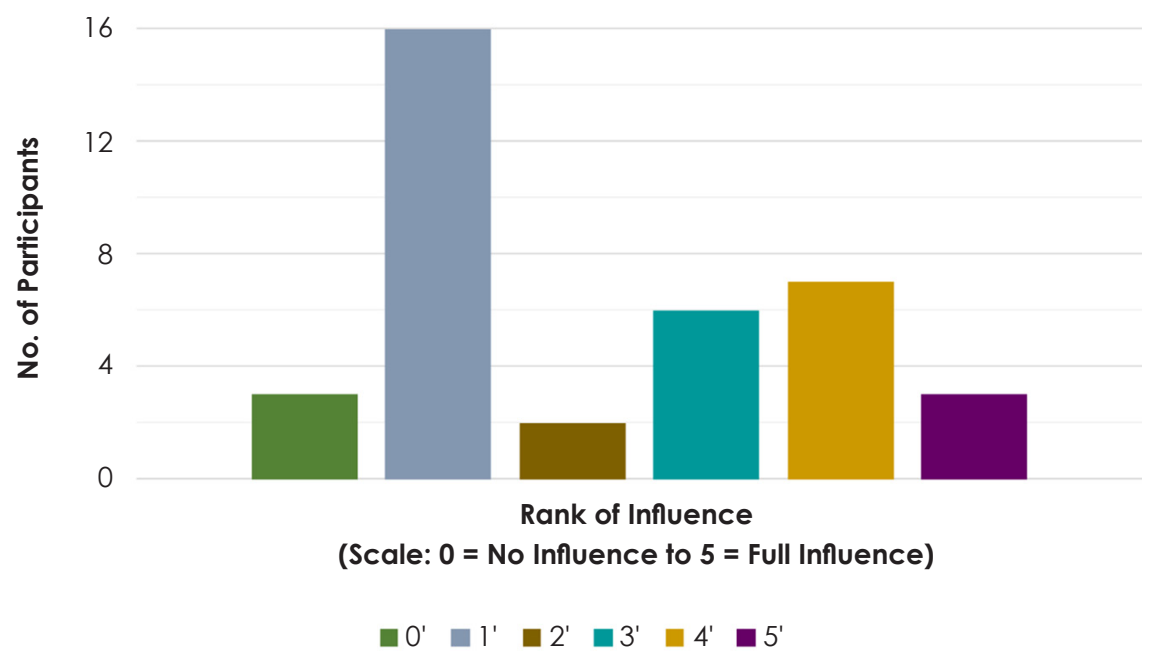

Figure 17. Investment in African Human Resource Training and Development (37 Answers/7 Skips) 


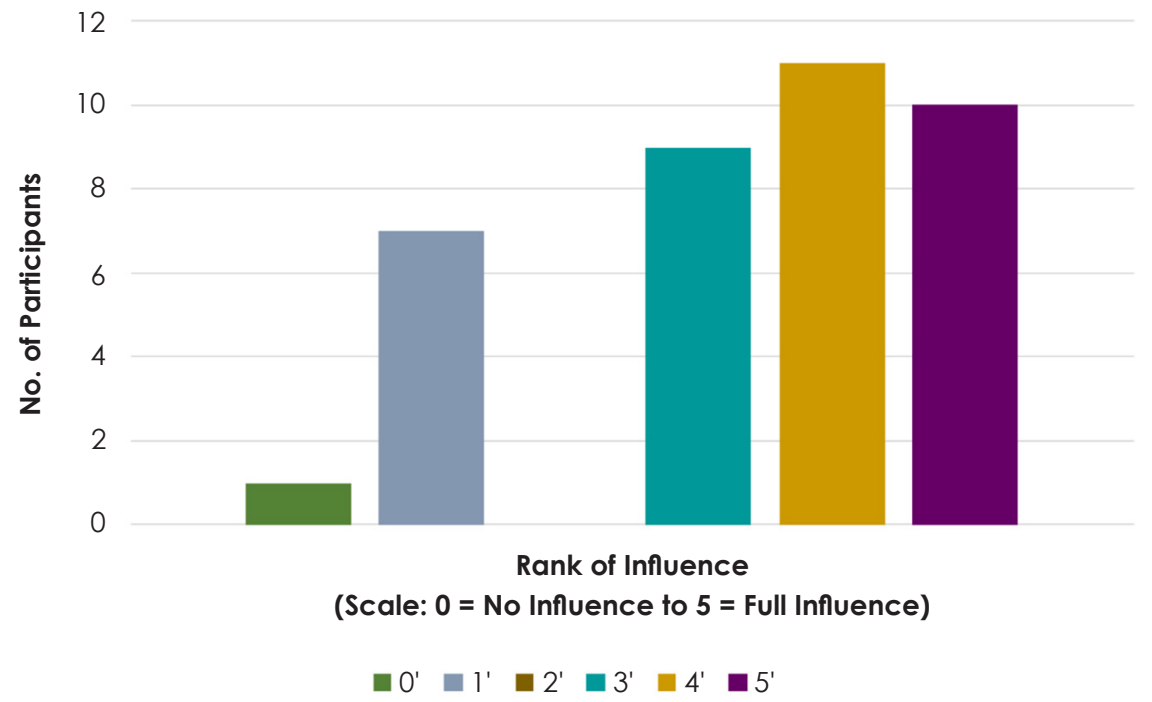

Figure 18. Capability to Trade Debt for Local Resources, Such As Wood, Land and Minerals (38 Answers/6 Skips)

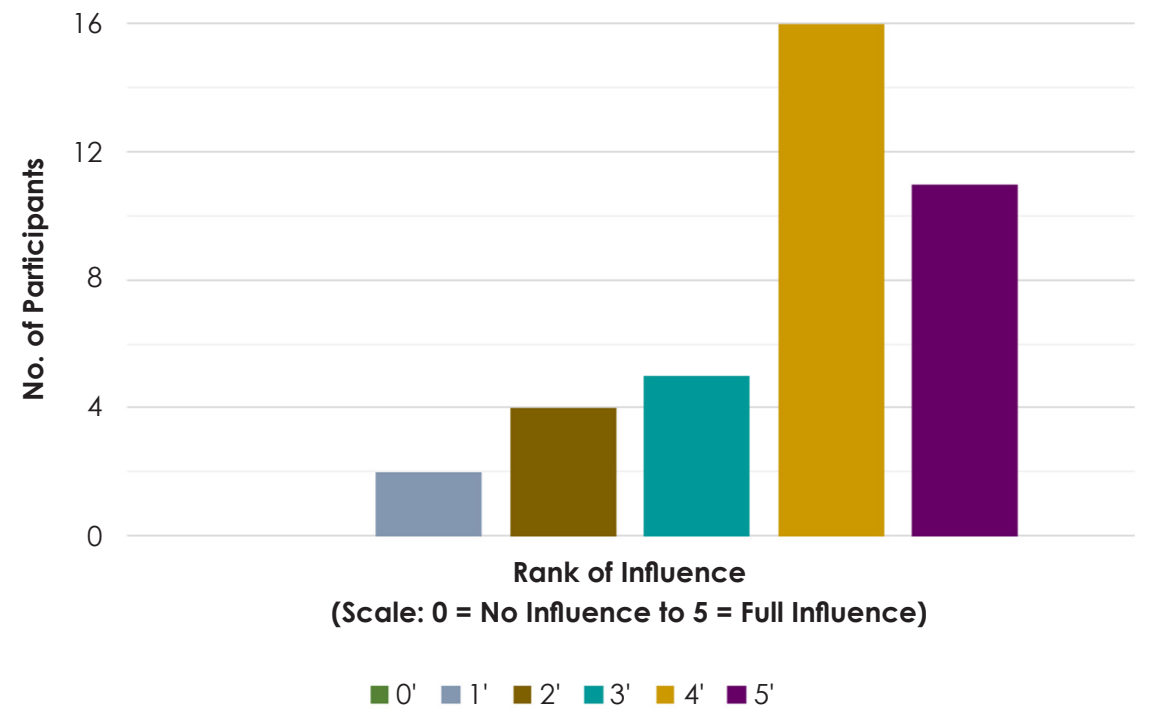

Figure 19. Capability to Offer All Types of Technical, Construction Associated Services and Funding Options to Their Clients (38 Answers/6 Skips) 


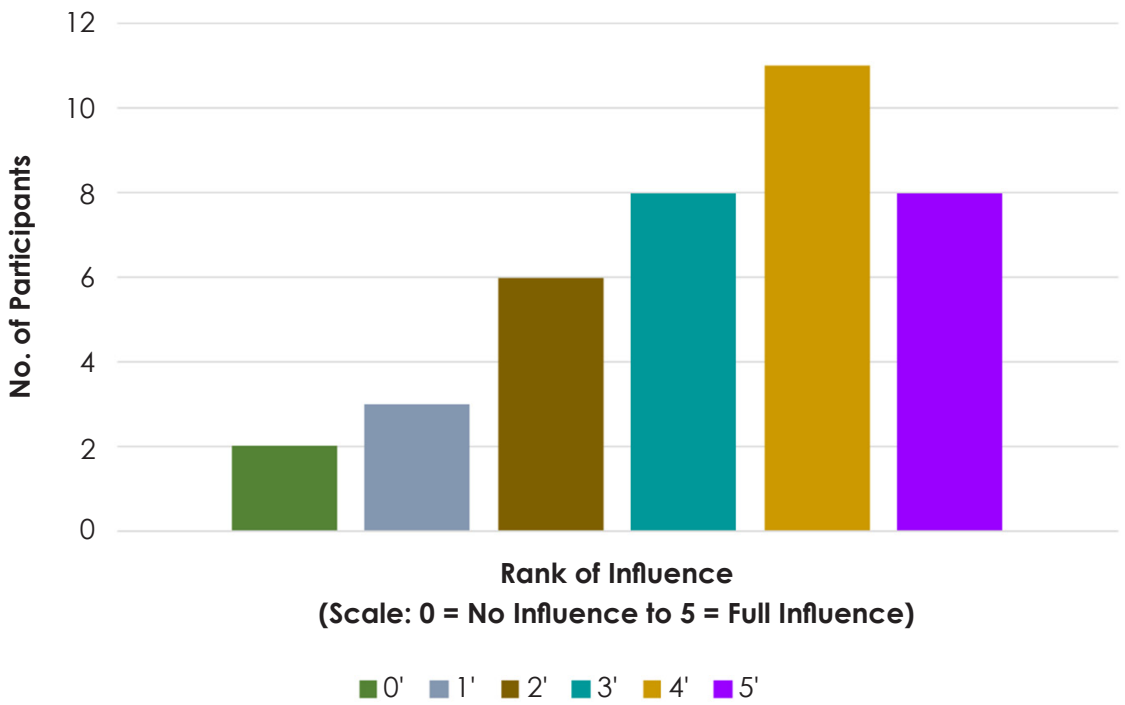

Figure 20. Capability to Offer and Deliver All Types of Contract Agreements to their Clients, Including Construction/Design and Build (or Design and Construction)/EPC/Build, Operate and Transfer (38 Answers/6 Skips)

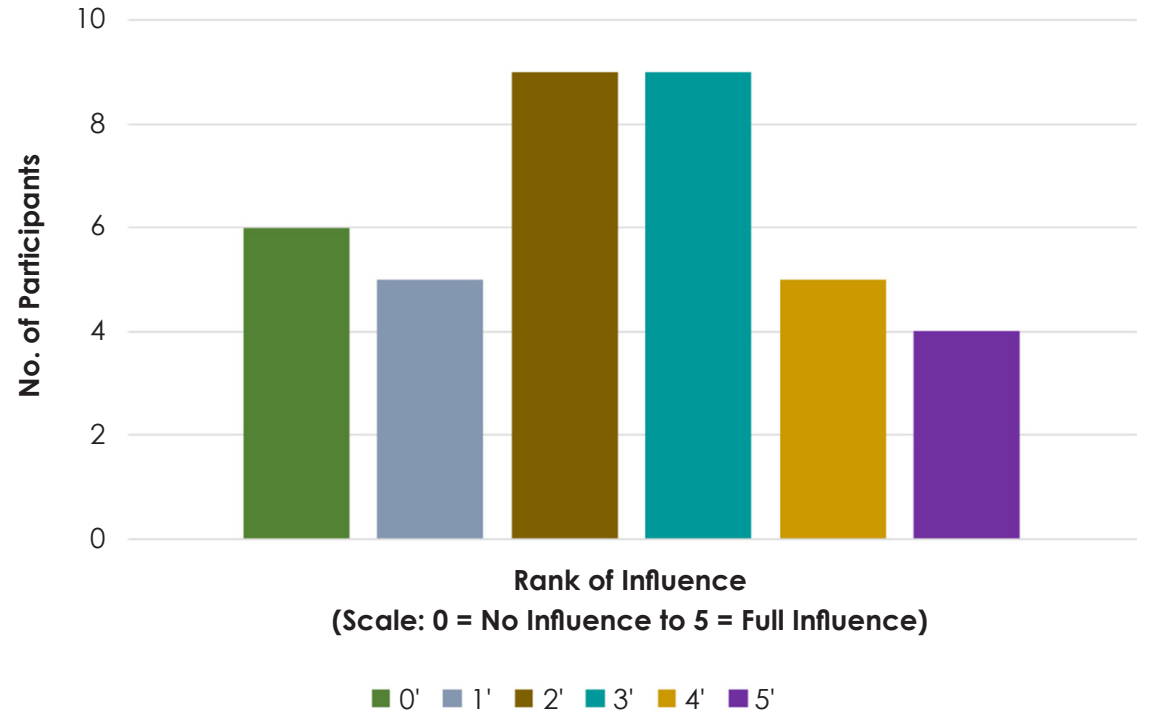

Figure 21. Creation of Dedicated and Specialised Sub-Companies (38 Answers/ 6 Skips) 
The first conclusive point can be taken from the results presented is that all organisational strategies identified are considered by the participants as important to the recent success of Chinese contractors in the region, as the average rank is 3 (mildly contributes to the success) or above (fully contributes to the success). The exception is the strategy-investment in African human resource training-which resulted in a "1" average score (low contribution), that Chinese contractors make low to non-investments in the training and development of local human resources.

The second conclusive point is that the capability to offer a lower price for construction services and the easy access to funds are the strategies that gathered higher rank 5 scores of the bunch, turning them into the most important strategies to the success of Chinese contractors operating in Southern Africa.

\section{Group analysis of the contribution of each organisational strategy to the recent success of Chinese contractor companies operating in the Southern African industry}

In this stage of the online survey, the results were similar to those from the independent analysis. All identified organisational strategies were considered by the participants as important to the recent success of Chinese contractors in the region and the strategies capability to offer a lower price for construction services and the easy access to governmental funds are the most voted. The least voted are training and development of local human resources and the creation of dedicated/specialised subsidiaries. The strategy of being capable to trade debt for local resources trails closely the top, in third place (as shown in Figure 22).

\section{Difficulty to implement strategies in the participant's organisation}

Easy access to loans and funds from the organisation's home government was the strategy voted as the most difficult to implement in their own companies by the questionnaire participants. The capability to offer lower prices for construction services and the capability to trade debt for local resources closely trail the former in 2 nd and 3rd places, respectively. At the other end of the scale, creation of dedicated and specialised subsidiaries, investment in human resource training and development and the capability to offer all types of technical, construction associated services and funding options to their clients represent the organisational strategies that are least difficult to implement in the participant's companies (as shown in Figure 23). 


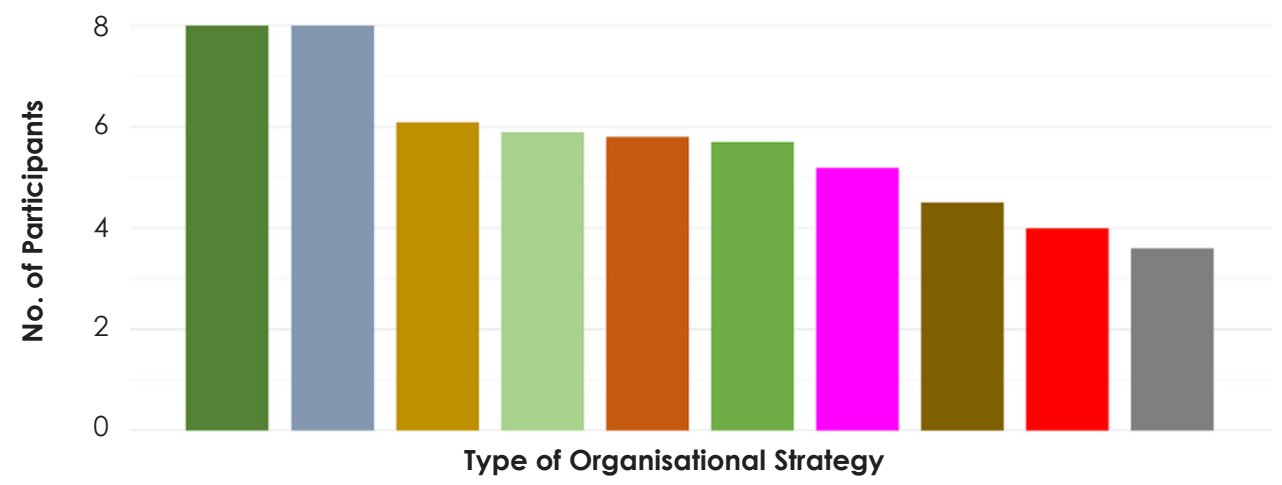

Easy access to loans and funds from the organisation's home government

- Capability to offer a lower price for construction services

Capability to trade debt for local resources, such as wood, land and minerals

Low adherence to compliance and anti-corruption policies

- Long-term partnerships with low-cost equipment and material suppliers

- Capability to offer all types of technical, construction associated services and funding options to their clients

- Capability to offer and deliver all types of contract agreements to their clients, such as build/design and build/engineering, procurement and construction/ build, operate and transfer

- Investment in Chinese human resource training and development

Investment in African human resource training and development

Creation of dedicated and specialised sub-companies

Figure 22. Organisational Strategies that Have Most Contributed to the Recent Success of Chinese Contractors in Southern Africa: Weighed Average Score (38 Answers/6 Skips) 


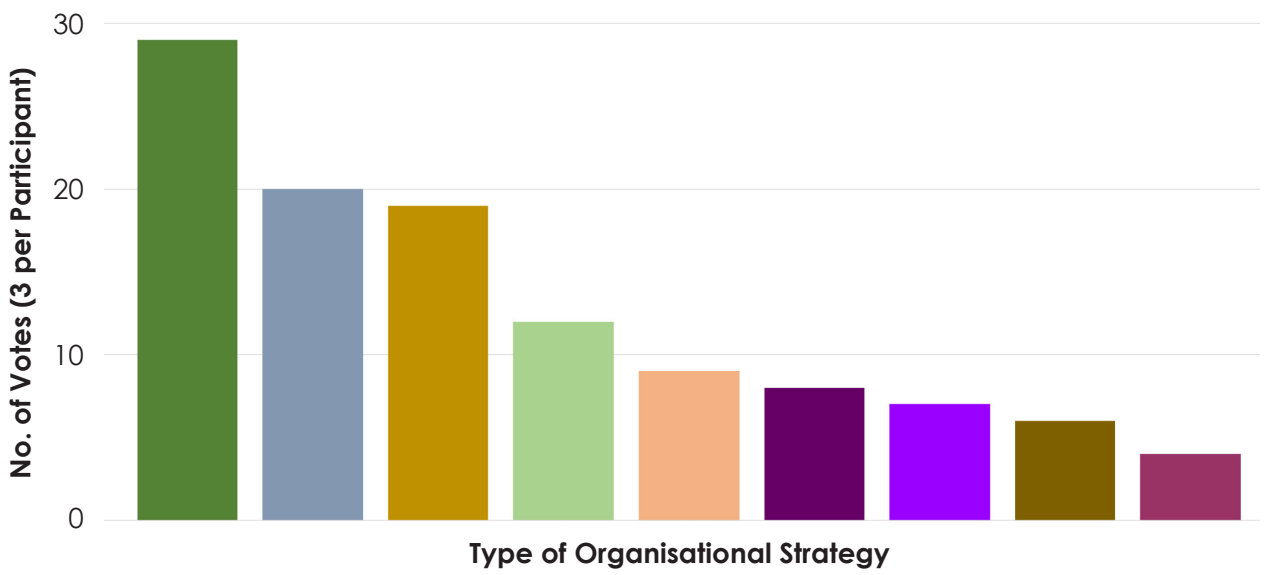

Easy access to loans and funds from the organisation's home government

Capability to offer a lower price for construction services

- Capability to trade debt for local resources, such as wood, land and minerals

Long-term partnerships with low-cost equipment and material suppliers

Low adherence to compliance and anti-corruption policies

- Capability to offer and deliver all types of contract agreements to their clients, such as build/design and build/engineering, procurement and construction/ build, operate and transfer

- Capability to offer all types of technical, construction associated services and funding options to their clients

- Investment in human resource training and development

Creation of dedicated and specialised sub-companies

Figure 23. Strategies that are Harder to Implement in Participant's Actual Organisation (38 Answers/6 Skips)

\section{Sustainability of the actual dominance of Chinese contractors in the Southern African construction industry}

The participants' opinion, regarding the sustainability of the actual Chinese contractor dominance in the Southern African construction industry, is purely split. Half of the participants that voted believes that the construction industry in the region will continue to be dominated by Chinese contractors and, the other half, believes that the actual dominance is based on fragile foundations, losing the created hegemony in a near future. Half of the respondents are impressed and convinced by the recent strategic and operational success of Chinese contractors, but the other group believes that the initial success may be temporary and can be retained only by the readiness to develop international business strategies that 
would enable them to participate long term in the global market. They need to harness their potential capacity towards globalising their businesses, strategies and operational frameworks that would foster their global competitiveness. The ability to manage cultural issues in multi-cultural situations as encountered on large construction projects significantly contribute to sustainability. The construction industry lags behind other sectors in its response to the problems of the environment but this is of critical importance in sustainability. Another aspect that Chinese firms can pursue is regarding the social inclusiveness of their project management efforts in whatever way possible in host countries. Figure 24 presents the results of the survey.

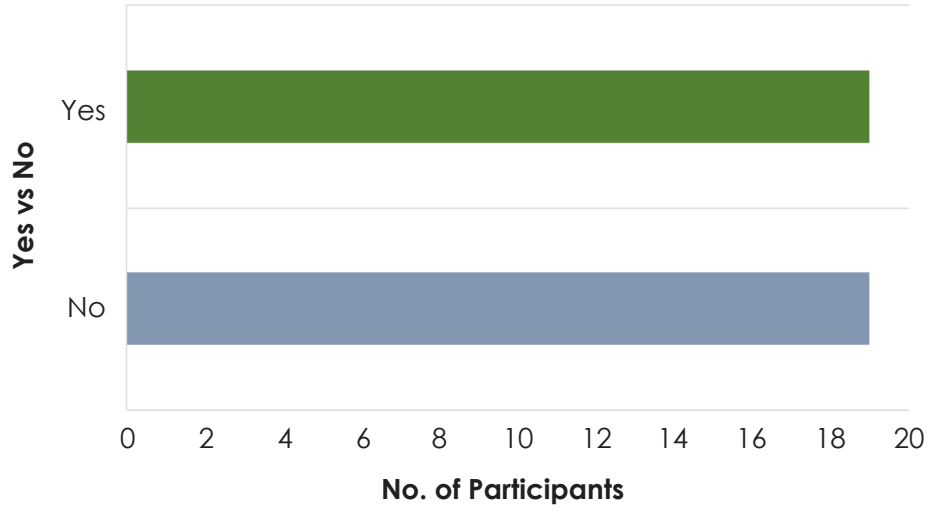

Figure 24. Sustainability of Actual Chinese Contractor Dominance in the Southern African Market (38 Answers/6 Skips)

\section{SUMMARY}

The study identified Angola, Tanzania, Zambia and Zimbabwe as the most prominent markets for Chinese multinational contractors, in the Southern African region.

In total, 11 Chinese multinational contractor companies were identified operating in the region and all of them are ranked highly in the ENR List of Top 250 International Contractors list.

The study identified 10 organisational strategies that were implemented and followed by the notorious Chinese contractor companies while the online questionnaire survey revealed that:

1. The capability to offer a low price for construction services, easy access to loans and funds from the Chinese government and the capability to trade debt for local resources are the organisational strategies that most contribute to the recent success endured by Chinese contractors in the Southern African construction industry.

2. The training and development of human resources and the creation of dedicated and specialised subsidiaries are the organisational strategies that least contribute to the recent success endured by Chinese contractors in the Southern African construction industry. 
3. The easy access to loans and funds from the organisation's home government, the capability to offer a low price for construction services and the capability to trade debt for local resources are the organisational strategies that competitor construction companies have more difficulty to implement and follow.

4. Human resources development and the creation of dedicated and specialised subsidiaries are the organisational strategies that are easier to implement by competitor construction companies.

5. Sustainability of the CMCCs in the construction industry of Southern Africa is inconclusive.

\section{ANSWERS TO THE RESEARCH QUESTIONS}

"How did a number of Chinese contractor companies grow from unprofitable firms, with a low local market share in their own country, to dominating the industry of construction overseas and in China and, such as in various countries of the Southern Africa region?"

The research revealed that the Chinese government invested greatly in the construction industry, domestically and internationally, by:

1. Upgrading the academic preparation and training of Chinese engineers, technicians and direct labour.

2. Empowering Chinese contractor companies to grow and develop by creating and implementing large and complex infrastructure projects in the country.

3. Financing construction projects worldwide.

4. Creating a synergy between different sectors of the Chinese industry and business, allowing the Chinese contractors to provide an unbeatable low-cost strategy.

5. Using construction as a direct drive to the country's economy and international politic relations.

"Which organisational strategies were developed and implemented that led to such growth?"

In total, through a literature review and a thorough study of the most successful Chinese contractor companies operating in the research location, 10 of the most significant organisational strategies were identified. They are:

1. capability to offer a lower price for construction services,

2. long-term partnerships with low-cost equipment and material suppliers,

3. easy access to loans and funds from the organisation's home government,

4. low adherence to compliance and anti-corruption policies, 
5. training and development of human resources from the organisation's home country,

6. training and development of human resources from the organisation's host country,

7. capability to trade debt for local resources, such as wood, land and minerals,

8. capability to offer all types of technical, construction associated services and funding options to their clients,

9. capability to offer and deliver all types of contract agreements to their clients, including construction/design and build (or design and construction)/EPC/build, operate and transfer and

10. creation of dedicated and specialised sub-companies.

"Which of the organisational strategies identified before contributed more to the growth and which contributed less?"

Through an online questionnaire focused on construction professional participants that have either worked with Chinese contractors or have proven experience and knowledge of the Southern African construction market it was possible to identify the following most influential strategies:

1. capability to offer a lower price for construction services,

2. easy access to loans and funds from the organisation's home government and

3. capability to trade debt for local resources, such as wood, land and minerals.

The training and development of human resources and the formation of dedicated and specialised subsidiaries are the organisational strategies that least contribute to the recent success endured by Chinese contractors in the Southern African construction industry.

"Can competitor companies easily adopt the impacting organisational strategies implemented by the Chinese multinational contractor firms?"

The online questionnaire survey revealed that the easy access to loans and funds from the organisation's home government, the capability to offer a low price for construction services and the capability to trade debt for local resources are the organisational strategies that are most difficult to implement in the participants' companies.

At the other end of the scale, human resources development and the creation of dedicated and specialised subsidiaries are the organisational strategies that are easier to implement by competitor construction companies. The remaining strategies rank between the mentioned scale terminals. 
The easy access to loans and funds from the Chinese government, the capability to offer a low price for construction services and the capability to trade debt for local resources are undoubtedly the strategies that transformed the competitive construction industry of Southern Africa into a blue ocean (Kim and Mauborgne, 2004; Manyika et al., 2013) for Chinese contractor companies.

In these three strategies, a clear unity between Chinese companies and the Chinese government exists, where one supports and protects the growth of the other. In a construction project, it is not only the contractor company that assumes the success of the project but an entire nation, that together, in perfect synergy, offer all the required technical and financial solutions to a client in need and at the same time, galvanise their economy and growth.

It is also important to refer that Chinese contractor companies invested seriously in upgrading and improving their technological knowledge and capabilities. They were able to achieve similar technological capabilities in regards to the competition. However, they are not capabilities that distinguish them or contribute positively to their competitive advantage. Nonetheless, they are capabilities that allow them to offer the same types of service, similar in quality, which allows them to equal, in terms of the service offer, their counterpart competitors.

\section{RECOMMENDATIONS}

Taking into consideration the findings of this study, it is possible to recommend improvements to both Chinese contractor companies and competitor companies operating in the construction industry.

To address, control and overcome the organisational image fragilities identified in the study, it is highly recommended for Chinese contractors to invest further in:

1. Health and safety management procedures and policies.

2. Compliance and anti-corruption procedures and policies.

3. Quality control and quality assurance procedures and policies.

4. Technical theoretical and practical training programs for the host country's human resources.

As for competitor contractor companies, it is highly advised that:

1. They review the status of all of the identified organisational strategies.

2. They develop and implement the ones that are fragile or inexistent, especially: The easy access to loans and funds from the organisation's home government, the capability to offer a low price for construction services and the capability to trade debt for local resources. 


\section{LIMITATIONS AND FUTURE RESEARCH SUGGESTIONS}

The study only revealed organisational strategies developed and implemented by the identified Chinese contractor companies. A myriad of other organisational strategies may exist that have the potential to further increase the competitive advantage of contractor companies. Majority of respondents did not belong to Chinese contractor organisations but have got indirect experience as employees in other market players who were bidders, competitors, subcontractors, client organisations etc. therefore the survey results were based in an external-internal viewpoint. Therefore, it is highly recommended in the future to conduct similar research focusing on other construction industry regions as well as conducting an online questionnaire survey where the population is mainly composed of professionals that are working in Chinese contractor companies. A final suggestion for future research is to study if the identified Chinese dominance is beneficial to the Southern Africa construction market in terms of profitability and competitiveness.

\section{REFERENCES}

Afonina, A. (2015). Strategic management tools and techniques and organizational performance: Findings from the Czech Republic. Journal of Competitiveness, 7(3): 19-36. https://doi.org/10.7441/joc.2015.03.02.

Altheide, D. and Johnson, J. (2011). Reflections on interpretive adequacy in qualitative research. In N. Denzin and Y. Lincoln (eds.), The SAGE Handbook of Qualitative Research. 4th Ed. Los Angeles: SAGE Publications, 581-594.

Bannister, S. (2007). Ethical issues and qualitative methods in the 21 st century: How can digital technologies be embraced in the research community? Journal of Ethnographic and Qualitative Research, 1(1): 1-10.

Berg, B. (2001). Qualitative Research Methods for the Social Sciences. 4th Ed. Boston: Allyn \& Bacon.

Birkinshaw, J., Hood, N. and Jonsson, S. (1998). Building firm-specific advantages in multinational corporations: The role of subsidiary initiative. Strategic Management Journal, 19(1): 221-241. https://doi.org/10.1002/(SICI) 1097$0266(199803) 19: 3<221::$ AID-SMJ948>3.0.CO;2-P.

Berinsky, A. (2006). American public opinion in the 1930s and 1940s: The analysis of quota-controlled sample survey data. The Public Opinion Quarterly, 70(4): 499-529. https://doi.org/10.1093/poq/nfl021.

Cheah, C., Kang, J. and Chew, D. (2007). Strategic analysis of large local construction firms in China. Construction Management and Economics, 25(1): 25-38. https://doi.org/10.1080/01446190600693450.

Chen, C., Chiu, P., Orr, R. and Goldstein, A. (2007). An empirical analyses of Chinese construction firms' entry into Africa. In The CRIOCM 2007 International Symposium on Advancement of Construction Management and Real Estate. Sydney: The Chinese Research Institute of Construction Management (CRIOCM).

Cheng, H. (2010). Chinese Companies and the International Engineering Contract Market in the 21 st Century: China Statistical Yearbooks (1996-2009). 2nd Ed. Beijing: China Statistical Publications. 
Chui, K. and Bai, Y. (2009). Comparison of Contract General Conditions between the US and China: Becoming More Competitive in the Chinese Construction Market. Saarbrücken, Germany: VDM Publishing House Ltd.

Corkin, L. (2011). Chinese construction companies in Angola: A local linkage perspective. In Making the Most of Commodities Programme (MMCP), Discussion Paper No. 2. Cape Town: University of Cape Town and Open University.

Creswell, J. (2011). Controversies in mixed methods research. In N. Denzin and Y. Lincoln (eds.), The SAGE Handbook of Qualitative Research. 4th Ed. Los Angeles: SAGE Publications, 269-284.

Dey, I. (2005). Qualitative Data Analysis: A User-Friendly Guide for Social Scientists. 3rd Ed. London: Routledge.

Easterby-Smith, M., Thorpe, R. and Jackson, P. (2012). Management Research. 4th Ed. London: SAGE Publications.

Erickson, F. (2011). A history of qualitative inquiry in social and educational research. In N. Denzin and Y. Lincoln (eds.), The SAGE Handbook of Qualitative Research. 4th Ed. Los Angeles: SAGE Publications, 43-60.

Ernest and Young (2017). China Communications Construction Company Limited: Annual Report 2016; Independent Auditor's Report. Shanghai: EY Press.

Fairholm, M. (2009). Leadership and organizational strategy. The Innovation Journal: The Public Sector Innovation Journal, 14(1): 1-16.

Flanagan, R., Lu, W., Ye, K. and Jewell, C. (2013). Developing construction professional services in the international market: SWOT analysis of China. Journal of Management in Engineering, 133(12): 302-313. https://doi. org/10.1061/(ASCE)ME.1943-5479.0000144.

Gabčanová, I. (2011). The employees: The most important asset in the organizations. Human Resources Management and Ergonomics, 5(1): 1-12.

Gale, N., Heath, G., Cameron, E., Rashid, S. and Redwood, S. (2013). Using the framework method for the analysis of qualitative data in multi-disciplinary health research. BMC Medical Research Methodology, 13(1): 1-8. https://doi. org/10.1186/1471-2288-13-117.

Ghahroudi, M. (2011). Ownership advantages and firm factors influencing performance of foreign affiliates in Japan. International Journal of Business and Management, 6(11): 119-137. https://doi.org/10.5539/ijbm.v6n1 1pl 19.

Goldman, E., Scott, A. and Follman, J. (2015). Organizational practices to develop strategic thinking. Journal of Strategy and Management, 8(2): 155-175. https://doi.org/10.1108/JSMA-01-2015-0003.

Hibberts, M., Johnson, R. and Hudson, K. (2012). Common survey sampling techniques. In L. Gideon (ed.), Handbook of Survey Methodology for the Social Sciences. New York: Springer, 167-211. https://doi.org/10.1007/978-14614-3876-2 5.

Johnson, B. and Turner, L. (2003) Data collection strategies in mixed methods research. In A. Tashakkori and C. Teddlie (eds.), Handbook of Mixed Methods in Social and Behavioral Research. London: SAGE Publications, 297-320.

Johnston, M. (2014). Secondary data analysis: A method of which the time has come. Qualitative and Quantitative Methods in Libraries (QQML), 3(1): 619626.

Kim, W. and Mauborgne, R. (2004). Blue ocean strategy. Harvard Business Review, 82(10): 76-84. 
Kinnie, N., Hutchinson, S., Purcell, J., Rayton, B. and Swart, J. (2005). Satisfaction with HR practices and commitment to the organization: Why one size does not fit all. Human Resource Management Journal, 15(4): 9-29. https://doi.org/10.1111/j.1748-8583.2005.tb00293.x.

Kotzé, T. (2007). Guidelines on Writing a First Quantitative Academic Article. 2nd Ed. Pretoria, South Africa: University of Pretoria Press.

Lan, Y. (2011). The expansion of Chinese construction companies in the global market. MSc diss. University of Kansas.

Larson-Hall, J. and Plonsky, L. (2015). Reporting and interpreting quantitative research findings: What gets reported and recommendations for the field. Language Learning, 65(1): 127-159. https://doi.org/10.1111/lang.12115.

Lo, F., Mahoney, J. and Tan, D. (2011). The relationship between locationbound advantages and international strategy: An empirical investigation. International Journal of Strategic Change Management, 3(4): 281-301. https://doi.org/10.1504/IJSCM.2011.044941.

Low, S. and Jiang, H. (2003). Internationalization of Chinese construction enterprises. Journal of Construction Engineering and Management, 129(6): 589-598. https://doi.org/10.1061/(ASCE)0733-9364(2003)129:6(589).

Low, S., Jiang, P. and Leong, C. (2004). A comparative study of top British and Chinese international contractors in the global market. Construction Management and Economics, 22(7): 717-731. https://doi.org/10.1080/ 0144619042000202780.

Lu, W., Liu, A., Rowlinson, S. and Poon, S. (2013). Sharpening competitive edge through procurement innovation: Perspectives from Chinese international construction companies. Journal of Construction Engineering and Management, 7(4): 347-351. https://doi.org/10.1061/(ASCE)CO.1943-7862.0000614.

Lu, W., Shen, L. and Yam, M. (2006). Critical success factors for competitiveness of contractors: China study. Journal of Construction Engineering and Management, 3(2): 972-982. https://doi.org/10.1061/(ASCE)07339364(2008) 1 34:12(972).

Manyika, J., Chui, M., Bughin, J., Dobbs, R., Bisson, P. and Mars, A. (2013). Disruptive technologies: Advances that will transform life, business and the global economy. Available at: http://www.mckinsey.com/insights/business_ technology/disruptive_technologies [Accessed on 17 February 2017].

Morse, J. (2003). Principles of mixed methods and multimethod research design. In A. Tashakkori and C. Teddlie (eds.), Handbook of Mixed Methods in Social and Behavioral Research. London: SAGE Publications, 189-208.

Mwangi, D. (2011). Competitiveness between local, EU and Chinese firms in Kenya. MSc diss. Copenhagen Business School.

Noon, M. (2007). The fatal flaws of diversity and the business case for ethnic minorities. Work, Employment and Society, 21 (4): 773-784. https://doi.org/ $10.1177 / 0950017007082886$.

Onwuegbuzie, A. and Teddlie, C. (2003). A framework for analyzing data in mixed methods research. In A. Tashakkori and C. Teddlie (eds.), Handbook of Mixed Methods in Social and Behavioral Research. London: SAGE Publications, 351384.

Pan, N. and Lee, M. (2017). Enhancing construction companies' marketing strategies: The construction industry in Taiwan. The International Journal of Organizational Innovation, 10(1): 143-164. 
Pheng, L., Shang, G. and Foong, W. (2016). Enhancing construction productivity through organizational learning in the singapore construction industry. International Journal of Construction Project Management, 8(1): 71-89.

Rumelt, R.P. (2003). What in the world is competitive advantage? Working Paper No. 2003-105. The Anderson School, University of California, Los Angeles (UCLA).

Sullivan, G. and Artino, A. (2013). Analyzing and interpreting data from Likerttype scales. Journal of Graduate Medical Education, 5(4): 541-542. https://doi.org/10.4300/JGME-5-4-18.

Survey Monkey (2017). Homepage. Available at: https://pt.surveymonkey.com/ [Accessed on 19 September 2017].

TiMetric (2018). Homepage. Available at: https://www.timetric.com/ [Accessed on 8 January 2018].

Tulacz, G. and Reina, P. (2017). The top 250 international contractors. ENR: Engineering News-Record, 5(1): 33-52.

. (2016). The top 250 international contractors. ENR: Engineering NewsRecord, 40(1): 37-58.

. (2015). The top 250 international contractors. ENR: Engineering NewsRecord, 16(1): 33-57.

. (2014). The top 250 international contractors. ENR: Engineering NewsRecord, 7(1): 1-20.

. (2013). The top 250 international contractors. ENR: Engineering NewsRecord, 45(1): 1-20.

. (2012). The top 225 international contractors. ENR: Engineering NewsRecord, 124(1): 1-19.

. (2011). The top 225 international contractors. ENR: Engineering NewsRecord, 13(1): 45-66.

. (2010). The top 225 international contractors. ENR: Engineering NewsRecord, 32(1): 44-66.

Turner, A. (2003). Sampling Strategies. New York: Statistics Division, United Nation Secretariat. Available at: http://unstats.un.org/unsd/demographic/ meetings/egm/Sampling_1203/docs/no_2.pdf [Accessed on 17 March 2018].

Williams, C. (2007). Research methods. Journal of Business and Economic Research, 5(3): 65-72. https://doi.org/10.19030/jber.v5i3.2532.

Yang, K. and Banamah, A. (2014). Quota sampling as an alternative to probability sampling?: An experimental study. Sociological Research Online, 19(1): 2949. https://doi.org/10.5153/sro.3199. 